\title{
Toxicology Studies on Lewisite and Sulfur Mustard Agents: Subchronic Toxicity Study of Lewisite in Rats
}

\section{Final Report}

L. B. Sasser, J. A. Cushing, D. R. Kalkwarf, P. W. Mellick and R. L. Buschbom

\author{
Pacific Northwest Laboratory \\ P.O. Box 999 \\ Richland, WA 99352
}

July 31, 1989

Supported by

U.S. Army Medical Research and Development Command

Fort Detrick, Frederick, MD 21701-5012

Army Project Order No. 84PP4865

Contracting Officer's Representative:

Jack C. Dacre, Ph.D., D.Sc.

Health Effects Research Division

U.S. Army Biomedical Research Division Laboratory

Fort Detrick, Frederick, MD 21701-5010

Approved for public release; distribution unlimited

The findings in this report are not to be construed as an official Department of the Army position unless so designated by other authorized documents. 


\title{
DISCLAIMER
}

This report was prepared as an account of work sponsored by an agency of the United States Government. Neither the United States Government nor any agency thereof, nor Battelle Memorial Institute, nor any or their employees, makes any warranty, expressed or implied, or assumes any legal liability or responsibility for the accuracy, completeness, or usefulness of any information, apparatus, product, or process disclosed, or represents that its use would not infringe privately owned rights. Reference herein to any specific commercial product, process, or service by trade name, trademark, manufacturer, or otherwise does not necessarily constitute or imply its endorsement, recommendation, or favoring by the United States Government or any agency thereof, or Battelle Memorial Institute. The views and opinions of authors expressed herein do not necessarily state or reflect those of the United States Covernment or any agency thereof.

\author{
PACIFIC NORTHWEST LABORATORY \\ operated by \\ BATTELLE MEMORIAL INSTITUTE \\ for the \\ UNITED STATES DEPARTMENT OF ENERGY \\ under Contract DE-AC06-76RLO 1830
}


REPORT DOCUMENTATION PAGE

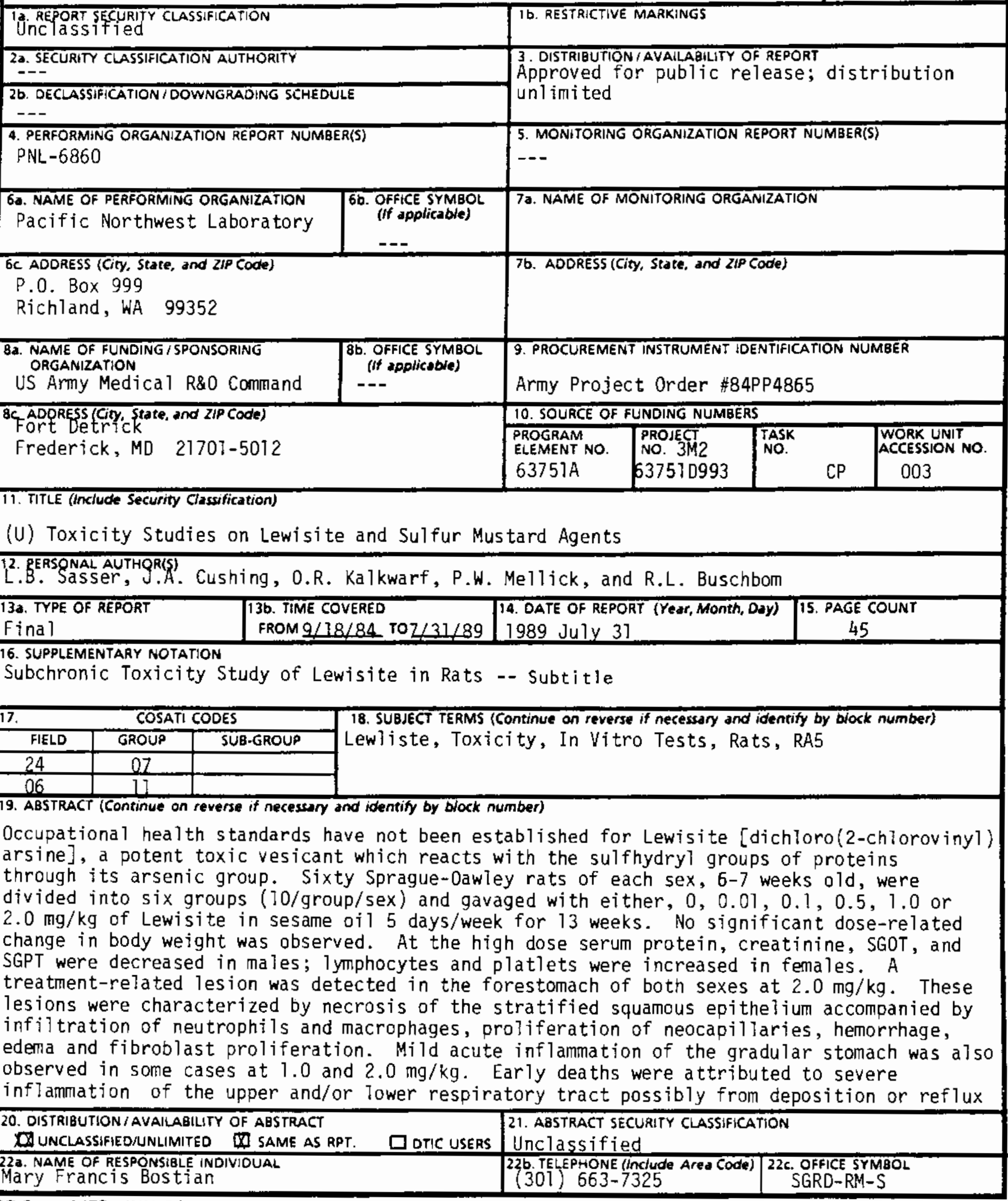


of test material into the pharynx. Estimated dose range for NOEL appears to be $>0.5$ and $<1.0 \mathrm{mg} / \mathrm{kg}$ when administered ora $11 \mathrm{y}$. 
Opinions, interpretations, conclusions and recommendations are those of the author and are not necessarily endorsed by the U.S. Army.

Where copyrighted material is quoted, permission has been obtained to use such material.

Where material from documents designated for limited distribution is quoted, permission has been obtained to use the material.

121 - Citations of commercial organizations and trade names in this report do not constitute an official Department of the Army endorsement or approval of the products or services of these organizations.

B In conducting research using animals, the investigator(s) adhered to the "Guide for the Care and Use of Laboratory Animals, "prepared by the Committee on Care and Use of Laboratory Animals of the Institute of Laboratory Animal Resources, National Research Council (NIH Publication No. 86-23, Revised 1985).

For the protection of human subjects, the investigator(s) have adhered to policies of applicable Federal Law 45CFR46.

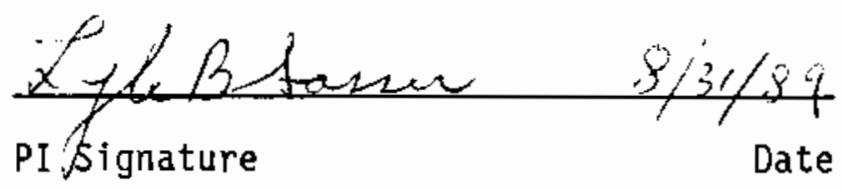



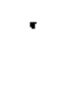


\section{EXECUTIVE SUMMARY}

Chemical warfare agents present an obvious risk to individual suffering acute exposure, but they may also present long-term environmental or occupational health hazards for workers in operations involving these chemical agents. Occupational health standards have not been established for Lewisite [dichloro(2-chTorovinyl)arsine] a strong alkylating agent with known mutagenic and suspected carcinogenic properties. Lewisite is used in a number of research laboratories, stored in depot sites throughout the country and occasionally transported to distant sites. The destruction of current stockpiles of Lewisite by the U.S. Army in the near future could create additional environmental and occupational risk. To establish a data base for setting environmental and occupational standards, we have conducted studies to evaluate the toxicity, mutagenicity, and reproductive effects of Lewisite using in vitro and in vivo study systems.

Solutions of Lewisite were prepared for administration by diluting the neat agent with sesame oil. Sixty Sprague-Dawley rats of each sex, 6-7 weeks old, were divided into six groups (10/group/sex) and gavaged with either 0 , $0.01,0.10,0.50,1.0$, or $2.0 \mathrm{mg} / \mathrm{kg}$ of Lewisite 5 days $/$ week for 13 weeks. A constant dosage volume of $1.67 \mathrm{ml} / \mathrm{kg}$ of body weight was given.

Body weights were measured weekly throughout the study and animals were observed twice each day of dosing for mortality and moribundity. Opthamology evaluations were performed at the beginning and termination of the study. Hematological evaluations were performed at 6 weeks and at the termination of the study. Serum BUN, creatinine, total protein, SGPT and SGOT were evaluated at terminal sacrifice. A complete gross necropsy was performed and a histopathological evaluation of collected tissue was made.

No significant dose-related change in body weight was observed. At the high dose serum protein, creatinine, SGOT, and SGPT were decreased in males; lymphocytes and platelets were increased in females. A treatment-related lesion was detected in the forestomach of both sexes at $2.0 \mathrm{mg} / \mathrm{kg}$. These lesions were characterized by necrosis of the stratified squamous epithelium accompanied by infiltration of neutrophils and macrophages, proliferation of neocapillaries, hemorrhage, edema and fibroblast proliferation. Mild acute inflammation of the glandular stomach was also observed in some cases at 1.0 
and $2.0 \mathrm{mg} / \mathrm{kg}$. Early deaths were attributed to severe inflammation of the upper and/or lower respiratory tract possibly from deposition or reflux of test material into the pharynx. Estimated dose range for NOEL appears to be $>0.5$ and $<1.0 \mathrm{mg} / \mathrm{kg}$ when administered orally. 
FOREWORD

EXECUTIVE SUMMARY. . . . . . . . . . . . . . . . . . . 4

INTRODUCTION . . . . . . . . . . . . . . . . . . . 8

MATERIALS AND METHODS. . . . . . . . . . . . . . . . 12

LEWISITE. . . . . . . . . . . . . . . . . 12

Procurement and Characterization ............ 12

Selection and Characterization of the Diluent. . . . . . . 12

Preparation of Solutions for Administration. . . . . . . . 13

Analyses of Lewisite Solutions ............... . 14

ANIMAL MAINTENANCE. . . . . . . . . . . . . . . . 18

Experimental Design. ................ 18

TOXICOLOGIC EVALUATIONS . . . . . . . . . . . . . . . . . 20

Hematological and Clinical Chemistry Evaluation. . . . . . 20

Necropsy and Histological Evaluations. . . . . . . . . 21

STATISTICAL METHODS . . . . . . . . . . . . . . . . 21

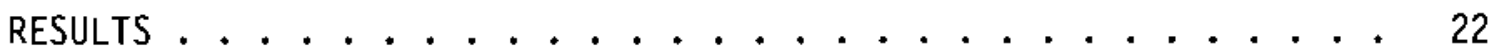

Necropsy and Histopathology. . . . . . . . . . . . 29

DISCUSSION . . . . . . . . . . . . . . . . . . . 34

LITERATURE CITED . . . . . . . . . . . . . . . . . 38

PERSONNEL LIST . . . . . . . . . . . . . . . . . . . . . 4 42

STUDY DATES FOR LEWISITE gO-DAY SUBCHRONIC STUDY . . . . . . . . . . . . 43

QUALITY ASSURANCE STATEMENT. . . . . . . . . . . . . . . . . . . . 44

DISTRIBUTION LIST. . . . . . . . . . . . . . . . . . . . 4 45

\section{APPENDICES}

A. ANALYTICAL CHEMISTRY REPORTS. .................. A-I

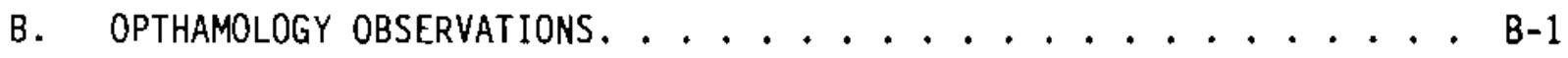

C. PATHOLOGY REPORT. ....................... C-1 


\section{LIST OF FIGURES}

$\underline{\text { Page }}$

1. The ratio of the analytical resuits to theoretical values as a function of time after preparation of dosing solution. . . .

2. Percent mortality of rats administered Lewisite in a 13-week subchronic study. . . . . . . . . . . . . . . . . .

3. Body weight of male (upper panel) and female (lower panel) rats exposed to Lewisite for 13 weeks. . . . . . . . . . . . .

\section{LIST OF TABLES}

1. Relevant chemical and physical data for Lewisite, dichloro(2-chlorovinyl)arsine................. 9

2. $L D_{50}$ values for Lewisite by various routes of administration . . 10

3. Analysis of sesame oil for peroxide. . . . . . . . . . 13

4. Lewisite dose levels and solution concentration for samples analyzed from the 90-day subchronic study. . . . . . . . . 16

5. Experimental design. . . . . . . . . . . . . . . 19

6. Body weights $(g)$ of male rats exposed to Lewisite. . . . . . . . 24

7. Body weights (g) of female rats exposed to Lewisite. . . . . . 25

8. The effect of Lewisite on red cells indices in male and female rats at 6 and 13 weeks of exposure . . . . . . . . . . . 27

9. The effect of Lewisite on white cell indices in male and female rats at 6 and 13 weeks of exposure ..............

10. The effect of Lewisite on serum concentrations of protein, BUN, creatinine, SGOT and SGPT of rats at 13 weeks of exposure. . . . 30

11. Final body weights and organ weights of rats orally exposed to Lewisite for 13 weeks. .................. 


\section{INTRODUCTION}

Chemical warfare agents present an obvious risk to individuals suffering acute exposures but may also present long-term environmental or occupational health hazards for workers in operations involving these chemical agents. Lewisite [dichloro(2-chlorovinyl)arsine], one of two major vesicant agents, presents a potential for accidental or occupational exposure because it is used in a number of research laboratories, stored in depot sites throughout the country and occasionally transported to distant sites. In addition, stockpiles of Lewisite are scheduled for destruction by the U.S. Army in the near future, creating an additional potential for environmental and occupational exposure. Although considerable information is known concerning the acute effects of Lewisite, little data are available on its long-term hazards. Segments of the population that may be particularly sensitive to its toxicity include the chronically $i 11$, the young and old, and the unborn. It is this concern that has prompted these studies to identify the potentially toxic, mutagenic and reproductive effects of Lewisite and to establish a data base for the development of hazard evaluations and occupational health standards for this chemical.

Lewisite is a highly toxic chemical vesicant. Unlike the strong alkylating vesicant sulfur mustard, Lewisite reacts with the sulfhydryl groups of proteins through its arsenic group (Cassarett and Doul1, 1986). In the presence of water or alkalies, Lewisite hydrolyzes to form Lewisite oxide, which is non-volatile and insoluble in water. Although few data are available, Lewisite oxide is generally thought to be a weaker vesicant (Gates et al., 1946) but its toxicity, has yet to be comprehensively studied. Relevant chemical and physical data for Lewisite is summarized in Table 1.

A comprehensive review which summarized the chemical and toxicity data of Lewisite acquired during World war I and World War II was published in 1946 (Gates et al., 1946). This review compared known human and animal data and concluded that sufficient toxicologic data were available for the determination of military usage. Lewisite exposure is characterized by immediate onset of pain, unlike the action of sulfur mustard in which pain may be delayed. The mucus membranes of the respiratory and gastrointestinal 
TABLE 1. Relevant Chemical and Physical Data for Lewisite, Dichloro(2-chloroviny 1) arsine*

Cas \#:

RTECS \#:

Structural formula:

Molecular weight:

Density at $20^{\circ} \mathrm{C}$ :

State:

Vapor pressure at $20^{\circ} \mathrm{C}$ :

Decomposition temperature:

Solubility in water:

Hydrolysis

Rate:

Products :
541-25-3

$\mathrm{CH} 2975000$

$\mathrm{Cl}-\mathrm{CH}=\mathrm{CH}=\mathrm{AsCl}$

$207.3 \mathrm{~g}$

$1.8 \mathrm{~B} 8 \mathrm{~g} / \mathrm{ml}$

and glass)

$0.394 \mathrm{~mm}$

$>100^{\circ} \mathrm{C}$

Very slightly soluble

Rapid

Chlorovinyl arsenous oxide, $\mathrm{HCl}$

(in acid solutions)

Acetylene, sodium arsenate

(in alkaline solutions)

*Rosenblatt et a1. 1975

tracts are particularly sensitive to Lewisite damage. Lewisite is not only a lethal vesicant but is also a systemic toxin; the liver, kidneys, gall bladder, bile duct and other organ systems are vulnerable to damage if absorption occurs (Cameron et al, 1946).

Exposures to Lewisite vapor produces edema of the respiratory tract and accumulation of pleural fluid (Gates, et al., 1946). Skin lesions resulting from contact with liquid Lewisite involve the rapid formation of an erythematous area, subsequent vesication and penetration of subcutaneous tissue so that edema and necrosis are evident. Man was less sensitive to skin lesion induction than the dog or rabbit. Systemic intoxication was evident in the dog a few hours following application of Lewisite (Gates et a1., 1946). Although sufficient anatomical lesions to characterize the immediate cause of death were not apparent, it was reported that fluid losses due to changes in capillary permeabitity did cause remarkable decreases in blood volume. Comparisons of toxic effects of Lewisite and sulfur mustard in dogs and rabbits indicated that Lewisite was more damaging to the skin and was more likely to induce systemic poisoning than was sulfur mustard. The 
acute $L_{50}$ values of Lewisite administered via different exposure routes to the rat, rabbit and guinea pig are presented in Table 2.

Table 2. LDse Values for Lewisite by Various Routes of Administration

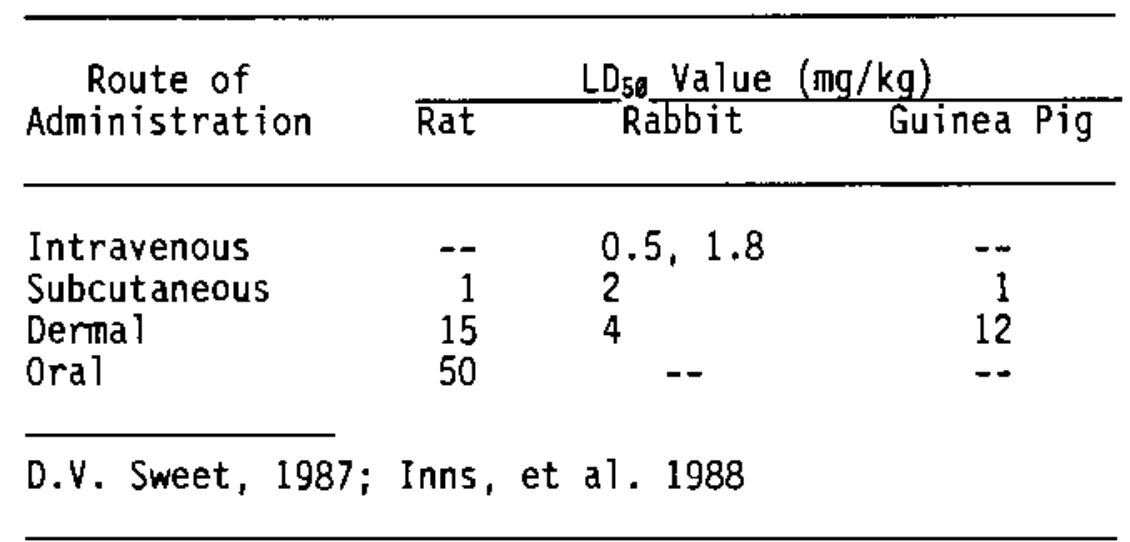

Few data are available to evaluate the potential chronic effects of Lewisite other than information based on anecdotal evidence from war use. Based on one incidence of accidental exposure to a soldier's leg, Lewisite is considered a suspect carcinogen in man (Krause and Grussendorf, 1978). Workers of a Japanese factory producing mustard and Lewisite agents during World War II had a high mortality rate due to respiratory and gastrointestinal cancers (Wada et al., 1968; Yamakido et al., 1985). These workers were potentially exposed to unknown quantities of both sulfur mustard and Lewisite; therefore, it is not possible to implicate Lewisite as a carcinogen because of possible confounding effects of the carcinogen, sulfur mustard.

Virtually no data were found on the mutagenicity of Lewisite in the Titerature. Auerbach (1947) found no mutagenic response in the fruit fly exposed to Lewisite and Loveless (1951) reported normal cellular division in root tips exposed to aqueous solutions of Lewisite. The teratogenic potential of Lewisite was studied by Hackett et al. (1987) in rats and rabbits using a segment II teratology protocol. Rats were exposed to 0.5 , 1.0 or $1.5 \mathrm{mg} / \mathrm{kg}$ Lewisite via gastric intubation from 6 to 15 days of gestation $(\mathrm{dg})$ and fetuses were examined on $\mathrm{dg} 20$. No evidence of a teratogenic response to Lewisite was observed. Likewise, fetal development 
of the rabbit exposed to 0.07 to $0.6 \mathrm{mg} / \mathrm{kg}$ Lewisite between 6 and $19 \mathrm{dg}$ was not affected even though maternal mortality was induced. These results suggest that Lewisite is not teratogenic in the rat or the rabbit after short term exposures since fetal effects were observed only at dose levels that induced maternal toxicity.

It is of interest that many of the symptoms of Lewisite and arsenic intoxication are similar (severe inflammation of the gastrointestinal tract with electrolyte disturbances and ulceration and perforation of membranes) (NAS, 1977) and raise the possibility that the systemic toxicity of Lewisite may result from its arsenic group. In alkaline solutions, Lewisite may hydrolyze to form acetylene and sodium arsenate. Leonard and Lauwerys (1980) reviewed the carcinogenicity, teratogenicity and mutagenicity of a wide variety of arsenic compounds. Some arsenic compounds were mutagenic in bacterial systems while others were not. In general all arsenic compounds tested in manmalian cell systems produced chromosomal aberrations, but no information is available for mutation induction in in vitro mammalian systems. Arsenic, as sodium arsenate or arsenite, is known to be embryotoxic and teratogenic in a number of animal species (Leonard and Lauwerys, 1980). In a comparison of Lewisite and sodium arsenite toxicity in the rabbit following intravenous administration, Inns et a1. (1988) reported that the $\mathrm{LO}_{58}$ values for sodium arsenite and Lewisite were not similar (7.6 and 1.8 $\mathrm{mg} / \mathrm{kg}$, respectively). Furthermore, significant differences in tissue arsenic content and pathology were reported for the two chemicals. Hackett et al. (1987) estimated that the arsenic uptake and accumulation from Lewisite exposure to maternal animals and their fetuses would not be significant at non-lethal doses in short-term teratology studies. However, arsenic accumulation may be important in long-term exposures.

Comprehensive data are not available to evaluate the potential risk from long-term occupational exposure to Lewisite. The purposes of this subchronic study were to define a No-Observed-Effect-Level (NOEL) in the rat, determine the target organ or organs with greatest susceptibility to the chemical agent and provide data to establish dose Tevels for subsequent multi-generation reproductive and dominant lethality studies. 
MATERIALS AND METHODS

\section{LEWISITE}

\section{Procurement and Characterization}

A shipment of $25 \mathrm{ml}$ dichloro(2-chlorovinyl)arsine (Lewisite, Agent L) was received from the U.S. Army Medical Research Institute of Chemical Defense (USAMRICD) on 7 March 1985. The chemical (Lot No. L-U-4273-CTF-N) was prepared by distillation on 30 September 1984 at the Chemical Research and Development Center (CRDC). The agent was analyzed by nuclear magnetic resonance ( $\mathrm{H}-1$ and $\mathrm{C}-13$; CRDC SOP No. 6-1-83-1, Annex F) at the Research Directorate, CRDC. Results of the analyses, expressed as calculated weight percent, were 95.8 and 4.0 for trans and cis isomers of dichloro(2-chlorovinyl)arsine, respectively, and 0.2 for unknown compounds.

The Lewisite was divided into two equal portions, pipetted into $30-\mathrm{ml}$ Wheaton vials, sealed and stored in secondary unbreakable containers in refrigerated storage at $\sim \sigma^{\circ} \mathrm{C}$. To comply with Good Laboratory Practices requirements, PNL has requested that USAMRICD retain an aliquot of this lot of Lewisite.

Lewisite was analyzed to detect the presence of common impurities, such as Lewisite oxide and the cis-trans isomers of bis $(2-$ chlorovinyl)chloroarsine and tris(2-chlorovinyl)arsine (Rosenblatt et al., 1975). Measurement of the ultraviolet absorption spectrum of the sample in isooctane revealed that the spectrum and the absorptivity of the material at $215 \mathrm{~nm}$ agreed with published values in the literature (Rewick, et al., 1986; Mohler and Sorge, 1939) and did not indicate the presence of ultraviolet-absorbing compounds other than Lewisite. This conclusion was supported by results from gas-chromatographic anaiyses of the sample following derivatization with 2-mercaptoethanol.

\section{Selection and Characterization of Diluent}

Lewisite is relatively insoluble and also is rapidly hydrolyzed in water; therefore, sesame oil was employed as the diluent for dosing solutions 
commonly the vehicle used for the administration of water-insoluble compounds; however, Hackett et al. (1987) reported from data in the literature that corn oil may not be appropriate for reproductive studies because of its high steroid content and recommended using sesame oil in their studies of the teratology of Lewisite. Sesame oil contains no preservatives, appears to be stable when stored under proper conditions, is relatively low in steroids and is readily available.

The sesame oil (Hain Pure Food Company, Los Angeles, CA) used in this study was purchased locally in one quart bottles and numbered according to lot and bottle. Peroxide analyses of each lot of sesame oil was performed at the beginning of the study or when purchased and periodically throughout the study to provide a measure of oxidation as an indication of rancidity of the oil. The method measures the ability of the oil to oxidize aqueous iodide. Only oil in which the peroxide content of less than $10 \mathrm{meq} / \mathrm{kg}$ was used in the study.

The results of the peroxide analyses of the sesame oit used are given in Table 3. The amount of peroxide in the sesame oil was well within the acceptable limits of $10 \mathrm{meq} / \mathrm{kg}$ set forth in the protocol.

TABLE 3. Analysis of Sesame 0il for Peroxide

\begin{tabular}{lcccc}
\hline Lot No. & Date Purchased & Assay 0ate & $\begin{array}{c}\text { Container } \\
\text { Identification }\end{array}$ & $\begin{array}{c}\text { Peroxide } \\
\text { meq } / \mathrm{kg}\end{array}$ \\
\hline $50775-95$ & $7 / 8 / 86$ & $11 / 17 / 86$ & 12 & 6.6 \\
$51564-6$ & $10 / 6 / 86$ & $10 / 07 / 86$ & 1 & 7.0 \\
& & $12 / 16 / 86$ & 4 & 7.7 \\
& $01 / 15 / 87$ & 6 & 8.7 \\
\hline
\end{tabular}

\section{Preparation of Solutions for Administration}

Lewisite was administered to the rats at $0.01,0.1,0.5,1.0$, and 2.0 $\mathrm{mg} / \mathrm{kg}$ of body weight using a constant volume-to-body weight ratio of 1.67 
$\mathrm{ml} / \mathrm{kg}$. Therefore, the Lewisite concentrations required to achieve these desired doses were $0.006,0.06,0.3,0.6$, and $1.2 \mathrm{mg} / \mathrm{ml}$, respectively.

The Lewisite dosing solutions administered to the animals were prepared in advance and stored in a refrigerator at approximately $6^{\circ} \mathrm{C}$. We have found that Lewisite is stable in sesame oil for 2-3 weeks when stored under these conditions. The general procedure was to determine in advance the amount of neat Lewisite needed, based on the volumes to be prepared and the final concentrations desired. This volume was then removed from the bottle of neat Lewisite and thoroughly mixed into a known volume of sesame oil. Aliquots of this intermediate concentration were then diluted further to give the final concentration needed for the dosing solutions. Aliquots of the final solutions were placed in wheaton bottles with teflon-lined septa and aluminum caps. Each wheaton bottle contained sufficient volume of Lewisite-sesame oil for 1 day's use. The bottles were labeled with the name and the concentration of the agent (Lewisite) and placed into a secondary unbreakable container which was identified by chemical name, concentration, lot number and date prepared.

\section{Analyses of Lewisite Solutions}

Lewisite in sesame oil was assayed by gas chromatography, using a capillary column and flame-ionization detection. Substantial analytical problems were encountered during our initial studies (dose-range and teratology studies in rats), and the procedure was subsequently modified for analyses of the solutions used in this study. The presence of high-boiling components in the sesame oil required that the temperature of the capillarycolumn inlet be maintained at $200^{\circ} \mathrm{C}$. Since the decomposition temperature for Lewisite is low $\left(190^{\circ} \mathrm{C}\right)$, it was necessary to develop an assay that would permit the migration of sesame oil through the column without any decomposition of the Lewisite. To solve this problem, a stable derivative of Lewisite in sesame oil was prepared by the addition of 2-mercaptoethanol. The reaction, which proceeds at room temperature, may be written:

$$
\mathrm{ClCH}=\mathrm{CHASCl}_{2}+2 \mathrm{HSCH}_{2} \mathrm{CH}_{2} \mathrm{OH} \rightarrow \mathrm{ClCH}=\mathrm{CHAs}\left(\mathrm{SCH}_{2} \mathrm{CH}_{2} \mathrm{OH}\right)_{2}+2 \mathrm{HCl}
$$


In the procedure developed for the analysis, Lewisite samples with concentrations $\leq 2.0 \mathrm{mg} / \mathrm{m} T$ were diluted $1: 10$ with isooctane prior to analysis. For the assay, $0.5 \mathrm{mT}$ of the sample was diluted with $0.5 \mathrm{~m} 1$ of a solution containing $120 \mathrm{ng}$ of 1-chloronaphthalene and $5584 \mathrm{ng}$ of 2-mercaptoethanol/ 1 in isooctane contained in a $1.5 \mathrm{ml}$ automatic sampler vial with a Teflonlined, crimped-top cap. The column (J\&W Scientific, DB-5) temperature program was $80^{\circ} \mathrm{C}$ for 5 min $\left(5^{\circ} / \mathrm{min}\right)$ to $140^{\circ} \mathrm{C}, 20^{\circ} / \mathrm{min}$ to $300^{\circ} \mathrm{C}$ and $300^{\circ} \mathrm{C}$ for 20 min. A Hewlett-Packard 5840A gas chromatograph and a 7672A automatic sample changer were used.

The results of the analyses for Lewisite in the solutions prepared for each 2-week period are shown in Table 4 . The results were within acceptable limits of analytical error for the $1.2 \mathrm{mg} / \mathrm{ml}$ concentration. As the Lewisite concentrations in the solutions decreased, the assay results became less acceptable. The method was not sufficiently sensitive to detect concentrations of Lewisite below $0.3 \mathrm{mg} / \mathrm{ml}$; therefore, values for the 0.06 and $0.006 \mathrm{mg} / \mathrm{ml}$ solutions are not given. The probable cause for the lack of sensitivity at low concentrations was interference by some constituents of the sesame oil, as sensitivity in organic solvents was greater than in sesame oil. The ratio for the analytical and theoretical values for the $1.2 \mathrm{mg} / \mathrm{ml}$ concentration is plotted in Figure 1. Lewisite was quite stable at this concentration in the sesame oil for 2 to 3 weeks. 
Table 4. Lewisite Dose Levels and Solution Concentration for Samples Analyzed from the 90-Day Subchronic Study (Mean $\ldots$ SE)

\begin{tabular}{|c|c|c|c|c|}
\hline \multirow{2}{*}{$\begin{array}{c}\begin{array}{c}\text { Date } \\
\text { Prepared }\end{array} \\
11 / 10 / 86\end{array}$} & \multirow{2}{*}{$\begin{array}{c}\begin{array}{c}\text { Date } \\
\text { Analyzed }\end{array} \\
11 / 10 / 86\end{array}$} & \multirow{2}{*}{$\begin{array}{c}\begin{array}{c}\text { Dose Level } \\
(\mathrm{mg} / \mathrm{kg})\end{array} \\
2.0 \\
\\
1.0 \\
0.5\end{array}$} & \multicolumn{2}{|c|}{$\begin{array}{l}\text { Lewisite Concentration }(\mathrm{mg} / \mathrm{ml}) \\
\text { Theoretical Analyzed* }\end{array}$} \\
\hline & & & $\begin{array}{l}1.20 \\
0.60 \\
0.30\end{array}$ & $\begin{array}{l}1.21 \neq 0.009 \\
0.507 \pm 0.021 \\
0.145 \pm 0.027\end{array}$ \\
\hline & $11 / 25 / 86$ & $\begin{array}{l}2.0 \\
1.0 \\
0.5\end{array}$ & $\begin{array}{l}1.20 \\
0.60 \\
0.30\end{array}$ & $\begin{array}{l}1.06=0.100 \\
0.55=0.005 \\
0.105\end{array}$ \\
\hline \multirow[t]{2}{*}{$11 / 21 / 86$} & $11 / 21 / 86$ & $\begin{array}{l}2.0 \\
1.0 \\
0.5\end{array}$ & $\begin{array}{l}1.20 \\
0.60 \\
0.30\end{array}$ & $\begin{array}{l}1.15 \neq 0.049 \\
0.540 \pm 0.009 \\
0.124 \pm 0.016\end{array}$ \\
\hline & $12 / 22 / 86$ & $\begin{array}{l}2.0 \\
1.0 \\
0.5\end{array}$ & $\begin{array}{l}1.20 \\
0.60 \\
0.30\end{array}$ & $\begin{array}{l}0.786 \neq 0.000 \\
0.222 \neq 0.046 \\
0.035 \neq 0.008\end{array}$ \\
\hline \multirow[t]{2}{*}{$12 / 05 / 86$} & $12 / 22 / 86$ & $\begin{array}{l}2.0 \\
1.0 \\
0.5\end{array}$ & $\begin{array}{l}1.20 \\
0.60 \\
0.30\end{array}$ & $\begin{array}{l}1.15=0.050 \\
0.54=0.009 \\
0.124=0.016\end{array}$ \\
\hline & $12 / 29 / 86$ & $\begin{array}{l}2.0 \\
1.0 \\
0.5\end{array}$ & $\begin{array}{l}1.20 \\
0.60 \\
0.30\end{array}$ & $\begin{array}{l}1.34 \neq 0.145 \\
0.352 \neq 0.036 \\
0.061=0.007\end{array}$ \\
\hline \multirow[t]{2}{*}{$12 / 19 / 86$} & $12 / 29 / 86$ & $\begin{array}{l}2.0 \\
1.0 \\
0.5\end{array}$ & $\begin{array}{l}1.20 \\
0.60 \\
0.30\end{array}$ & $\begin{array}{l}1.21 \neq 0.008 \\
0.456 \pm 0.068 \\
0.069 \pm 0.004\end{array}$ \\
\hline & $01 / 07 / 86$ & $\begin{array}{l}2.0 \\
1.0 \\
0.5\end{array}$ & $\begin{array}{l}1.20 \\
0.60 \\
0.30\end{array}$ & $\begin{array}{l}1.24=0.398 \\
0.361 \neq 0.012 \\
0.051 \pm 0.008\end{array}$ \\
\hline \multirow[t]{2}{*}{$01 / 06 / 87$} & $01 / 06 / 87$ & $\begin{array}{l}2.0 \\
1.0 \\
0.5\end{array}$ & $\begin{array}{l}1.20 \\
0.60 \\
0.30\end{array}$ & $\begin{array}{l}1.06 \neq 0.139 \\
0.223 \neq 0.021 \\
0.066 \neq 0.004\end{array}$ \\
\hline & $01 / 30 / 87$ & $\begin{array}{l}2.0 \\
1.0 \\
0.5\end{array}$ & $\begin{array}{l}1.20 \\
0.60 \\
0.30\end{array}$ & $\begin{array}{l}0.953 \neq 0.075 \\
0.209 \neq 0.011 \\
0.032 \neq 0.001\end{array}$ \\
\hline $01 / 15 / 87$ & $01 / 29 / 87$ & $\begin{array}{l}2.0 \\
1.0 \\
0.5\end{array}$ & $\begin{array}{l}1.20 \\
0.60 \\
0.30\end{array}$ & $\begin{array}{l}1.20 \neq 0.002 \\
0.287 \neq 0.013 \\
0.091 \neq 0.063\end{array}$ \\
\hline
\end{tabular}


Table 4. Continued

\begin{tabular}{lcccc}
\hline $\begin{array}{c}\text { Date } \\
\text { Prepared }\end{array}$ & $\begin{array}{c}\text { Date } \\
\text { Analyzed }\end{array}$ & $\begin{array}{c}\text { Dose Level } \\
(\mathrm{mg} / \mathrm{kg})\end{array}$ & $\begin{array}{l}\text { Lewisite Concentration }(\mathrm{mg} / \mathrm{ml}) \\
\text { Theoretical }\end{array}$ \\
\hline $01 / 15 / 87$ & $02 / 10 / 87$ & 2.0 & 1.20 & $0.939 \pm 0.110$ \\
& & 1.0 & 0.60 & $0.224 \pm 0.001$ \\
& 0.5 & 0.30 & $0.019 \pm 0$ \\
$01 / 30 / 87$ & $02 / 10 / 87$ & 2.0 & 1.20 & $1.01 \pm 0.19$ \\
& & 1.0 & 0.60 & $0.30 \pm 0.043$ \\
& & 0.5 & 0.30 & $0.059 \pm 0.005$ \\
\hline
\end{tabular}

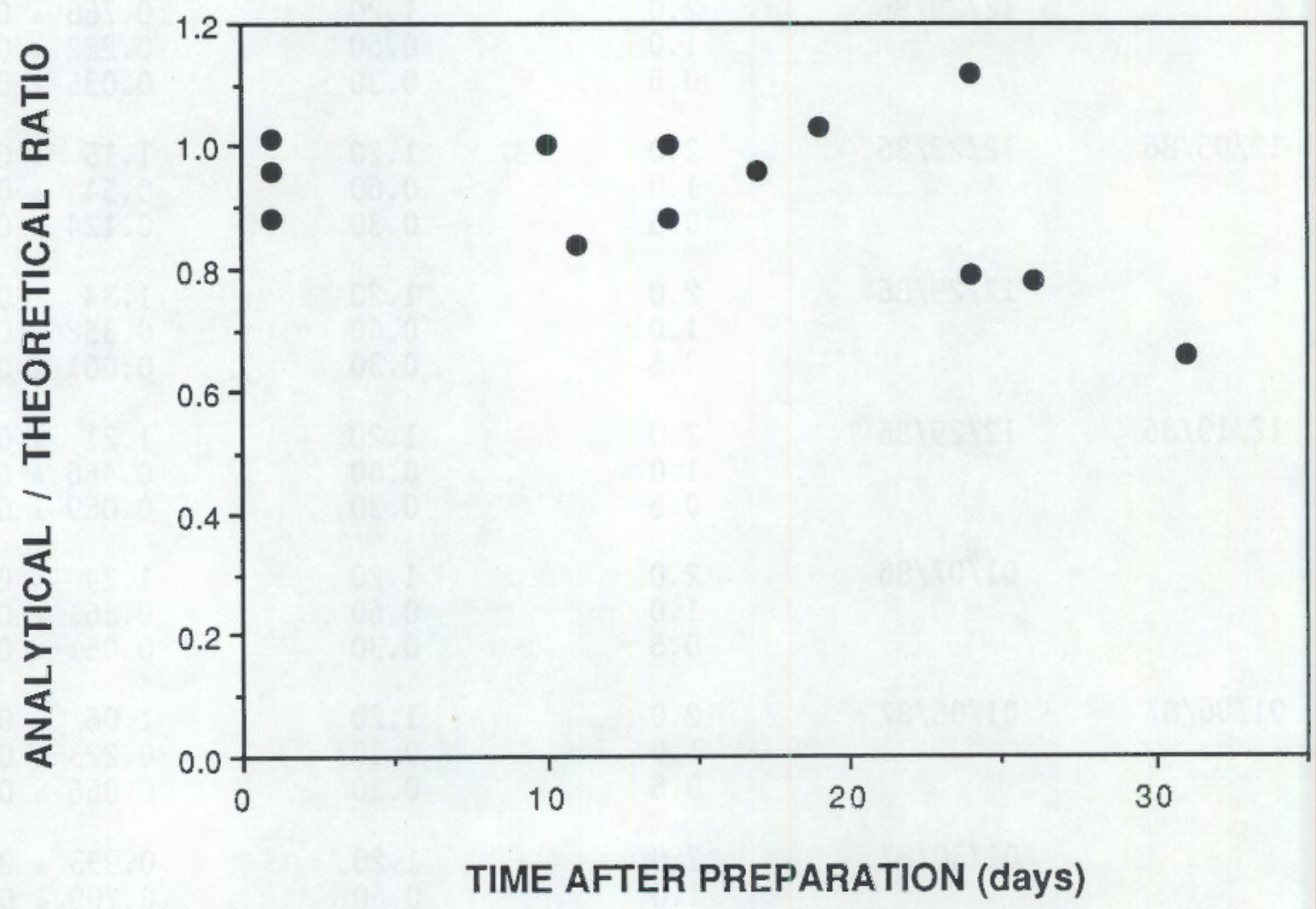

Figure 1. The ratio of the analytical results to theoretical values as a function of time after preparation of dosing solution. 
ANIMAL MAINTENANCE

Four-week old male and female rats of Sprague-Dawley derivation were obtained from Charles River Laboratories, Inc., Raleigh, NC facility and quarantined in isolation for about 3 weeks until a health evaluation could be completed. The Sprague-Dawley rat was selected because it has been used in a number of previous reproductive studies at PNL including gavage studies of Lewisite and background information was available for estimating doses. During quarantine the rats were group housed, separated by sex, in stainless-steel wire bottom cages placed on automatic flush racks with an automatic watering system.

The environmental conditions specified for the animal rooms were temperatures of $72 \pm 3^{\circ} \mathrm{F}$, relative humidity of $50 \pm 15 \%$, and a lighting cycle of 12 hours on and 12 hours off. Certified Rodent Chow ( $\# 5002)$ from Purina and drinking water were provided ad libitum. Drinking water supplied to the animal rooms was passed through a reverse-osmotic purification unit and containing two particle filters and a carbon filter.

Near the end of quarantine ten rats, 5 males and 5 females, were subjected to a health evaluation and tested for antibodies to viral pathogens. No significant pathogens or lesions were found.

Following isolation the rats were weighed and assigned to the appropriate treatment groups by sex and weight by means of a formal randomization statistical package (see Statistical Methods). Each animal was assigned an individual identification number by means of a metal ear tag. The animals were individually housed as described above and cage cards were used to indicate the animal number and treatment group.

\section{Experiment Design}

The experimental design for the 90-day subchronic study is described below in Table 5. Ten 9-week old weanling rats of each sex were assigned to one of five treatment groups or to the vehicle control group. Solutions of appropriate concentrations of Lewisite in sesame oil were administered to the animals by intragastric intubation 5 days per week for 13 weeks or approximately 65 dosing days. The animals were weighed each week and the 
weekly doses for individual animals were calculated from their body weight. A constant dosage volume of $1.67 \mathrm{ml} / \mathrm{kg}$ of body weight was given.

TABLE 5. Experimental Design

\begin{tabular}{lcccc}
\hline & $\begin{array}{c}\text { Number of } \\
\text { Animals/ } \\
\text { Level }\end{array}$ & $\begin{array}{c}\text { Number of } \\
\text { Sexes }\end{array}$ & $\begin{array}{c}\text { Number of } \\
\text { Dose Levels }\end{array}$ & Total \\
\hline HD Exposure Groups & 10 & 2 & 5 & 100 \\
Vehicle control & 10 & 2 & 1 & -- \\
Health screen & -- & -- & 10 \\
Total & & & 130 \\
\hline
\end{tabular}

The doses selected for this study were based on data obtained from a short-term dose-range study and a teratology study (Hackett et al. 1987). It appeared from these studies that the dose-response of Lewisite for lethality in the rat was very steep; therefore, the upper three dose levels for this study were set using a sequential two-fold reduction whereas the remaining two levels were spaced by five- and ten-fold reductions, respectively. The resulting dose-levels were $2.0,1.0,0.5,0.1$ and $0.01 \mathrm{mg} / \mathrm{kg}$ of body weight.

Oral exposure was specified by the sponsor for this study. The expected routes of environmental exposure are inhalation, dermal exposure, or ingestion, either direct or from swallowing inhaled material. Oral exposure was selected over inhalation, dermal application and subcutaneous or intraparietal injection for a number of reasons. It was considered impractical to expose by inhalation because of low tolerance of the respiratory tract to Lewisite, the potential hazards to personnel, technical aspects of generating the agent and the cost of a long-term inhalation exposure. Direct application to the animal was not desirous because of hazards incurred while handling the animals and the possible development of lesions after long-term exposure which could affect the translocation of material to the body. Injection of the material was ruled out because of the potential of local lesions from multiple injections of the agent. 


\section{TOXICOLOGIC EVALUATIONS}

Individual animals were weighed immediately prior to initiation of chemical treatment, at weekly intervals throughout the study, prior to necropsy of moribund or dead animals and at terminal sacrifice. All animals were observed twice daily, morning and afternoon, of each day of dosing for mortality and moribundity. Daily observations were also made on each nondosing day. All animals were evaluated weekly for clinical signs of toxicity. Ocular evaluations were performed for control, 2.0 and $1.0 \mathrm{mg} / \mathrm{kg}$ animals prior to the study and prior to necropsy.

\section{Hematological and Clinical Chemistry Evaluation}

The general provisions of the National Toxicology Program (NTP) July 1984 General Statement of Work was utilized in the hematology and clinical chemistry evaluations. Blood specimens were obtained from the retro-orbital plexus of all study animals for hematological evaluation at the 6 th week of the study.

An Othro Elt-8/ds multiparameter hematologic evaluation was determined for the following parameters: platelets, leukocytes, red blood cell (RBC) count, hemoglobin concentration, volume of packed red cells (VPRC), mean corpuscular volume (MCV), mean corpuscular hemoglobin (MCH), and mean corpuscular hemoglobin concentration (MCHC). Blood smears were stained with Wright/Giensa stain in a Gam-Rad automated stainer. Leukocyte differential counts were based on classifying a minimum of 100 leukocytes. Reticulocytes, stained supravitally with New Methylene Blue, were enumerated using the Miller disc method.

Clinical chemistry was evaluated only at terminal sacrifice. Blood was collected without anticoagulants from the retro-orbital plexus of the anesthetized rat. Following centrifugation of the blood sample, the serum was removed and assayed immediately for urea nitrogen (BUN), creatinine, total serum protein, serum glutamic pyruvic transaminase (SGPT) and glutamic oxaloacetic transaminase (SGOT) using an Abbot VP Chemistry unit. 
Necropsy and Histological Evaluations

A complete gross necropsy was performed on all rats found dead or in moribund condition and those killed at the scheduled terminal sacrifice. Live animals were euthanized with $70 \% \mathrm{CO}_{2}$ within 24 hours of the last two consecutive dosings and immediately necropsied. Weights were taken of liver, thymus, right kidney, right gonad, heart, brain and adrenals. Tissues were stored in $10 \%$ neutral buffered formal in (NBF).

To standardize the degree of distension of pulmonary alveoli with fixative, the lungs were fixed by inserting a blunted needle into the laryngeal lumen through which the fixative was infused ( $10 \% \mathrm{NBF})$.

Tissues from 10 male and 10 female rats of the $2.0 \mathrm{mg} / \mathrm{kg}$ and control groups were examined microscopically. Target organs identified in the 2.0 $\mathrm{mg} / \mathrm{kg}$ group were examined successively in the next lower doses until no effect was found. Histopathologic diagnoses were tabulated in the Microscopic Pathology Incidence Table.

\section{STATISTICAL METHODS}

The PNL derived computer software program for randomizing animals into experimental groups is based on a single blocking factor for animal weight. Animal weights for a given study are ordered from lightest to heaviest; blocks of animal weights are then randomly assigned to the treatment groups and the control group. Block sizes are governed by the number of test groups.

Analys is of variance was used to analyze weight, hematology and clinical chemistry data (SAS, 1985). If the results of the analyses were significant, Tukey's Studentized Range Test was used to delineate intergroup differences among means (Tukey, 1953). An orthogonal contrast was used to test for a trend in the results repeated over time on the same animal, a randomization test was used to test for differences among growth curves (Zerbe, 1979). This test is a nonparametric statistical test that is based on the absolute area between growth curves and allows for correlation of body-weight measurements over time. 


\section{RESULTS}

There were 30 animals in the study that did not survive until the scheduled sacrifice. One male animal $(1.0 \mathrm{mg} / \mathrm{kg})$ died, apparently of an overdose of anesthetic, while being bled for the histological evaluation at week 6 of the study. The remaining 29 animals died, or were killed in a moribund condition, of treatment related effects associated with the dosing of the animals. This included 2 males and 3 females of the $0.5 \mathrm{mg} / \mathrm{kg}$ group, 8 males and 6 females of the 1.0 dose group and 3 males and 7 females of the 2.0 dose group. Deaths occurred during the first week of the study and continued throughout the study. Although all the deaths occurred in the three highest dose groups, the incidence was not particularly dose-dependent (Figure 2).

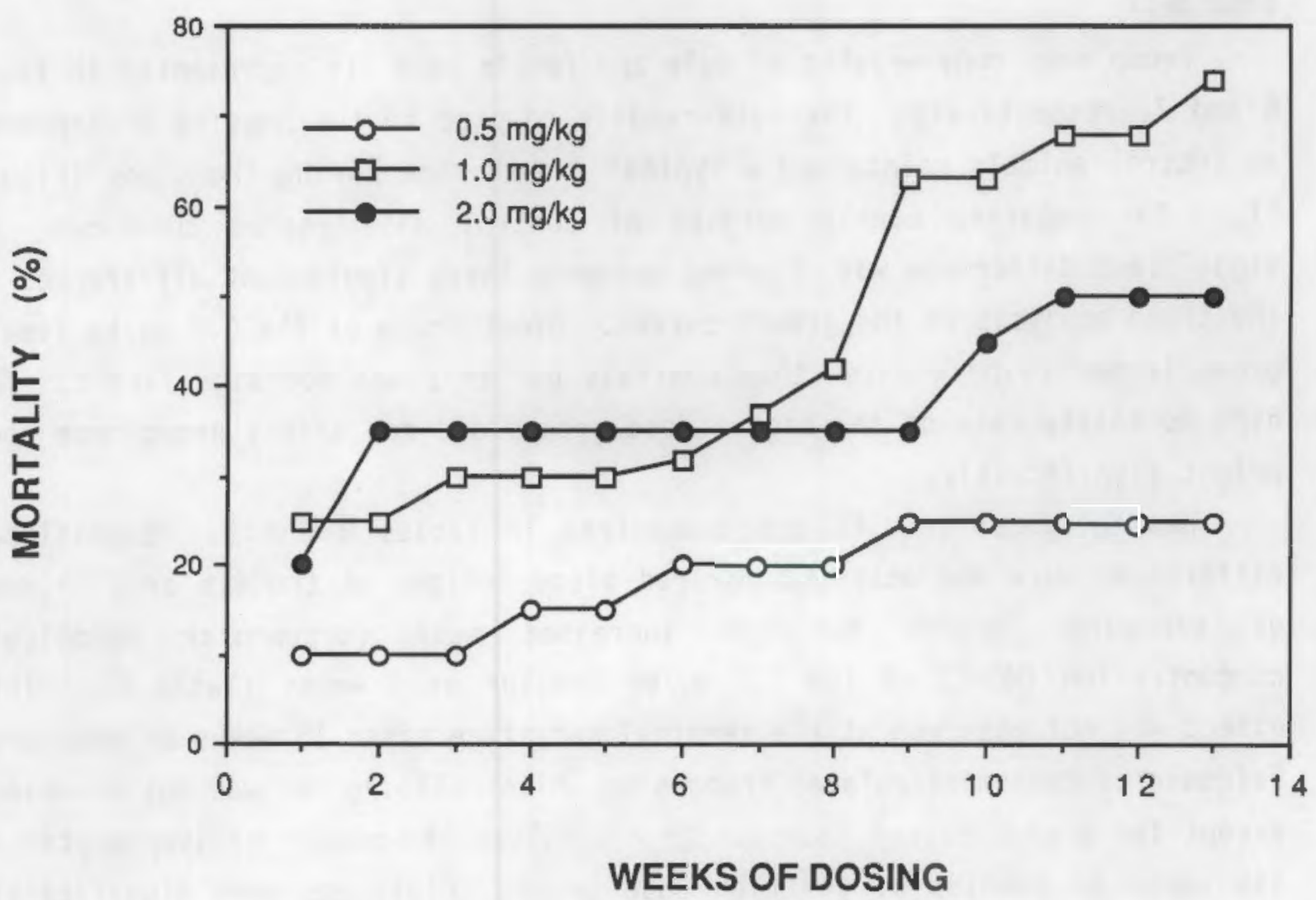

Figure 2. Percent mortality of rats administered Lewisite in a 13-week subchronic study. 
The majority of the animals were without abnormal signs until a day or two prior to death, although several animals died without clinical signs being observed. The initial signs including drooling or wetness around the mouth and chin and light to heavy mouth breathing, were usually observed after dosing of the animals. Evidence of drooling was present at other times from dry stains around the mouth. Typical signs in the more advanced cases included dyspnea, drooling and listlessness.

Weekly clinical observations of behavior, respiration, skin and hair coat and fecal material revealed no significant changes in control, 0.01 or $0.1 \mathrm{mg} / \mathrm{kg}$ animals. Signs of drooling, nasal discharge and occasional light mouth breathing were observed in survivors of the 3 highest treatment groups. These signs were usually observed after dosing. Death, as described above, usually resulted if these signs became more severe. Ocular damage was observed in a number of animals after orbital bleeding for hematological evaluation at 6 weeks, but none of these effects were not attributed to treatment.

Group mean body weights of male and female rats are represented in Table 6 and 7, respectively. The rats readily adapted to the housing environment as control animals maintained a typical growth rate during the study (Figure 3). In comparing weekly weights of control and treated survivors, no significant difference was observed nor were there significant differences in the trend analysis of the growth curves. Growth rate of the $0.5 \mathrm{mg} / \mathrm{kg}$ female group tended to be greater than controls but this was not significant. The high mortality rate of the higher dose groups did not affect group mean body weight significantly.

Hematological results are summarized in Tables 8 and 9 . Significant differences were not observed for red blood indices at the 6 th or 13 th week of exposure, except for the increased mean corpuscular hemoglobin concentration (MCHC) of the $2.0 \mathrm{mg} / \mathrm{kg}$ females at 6 weeks (Table 8). This effect was not observed at the terminal sacrifice after 13 weeks of exposure. Evidence of treatment-related changes in white cell indices was not observed, except for a significant increase $(P<0.05)$ in the number of lymphocytes at six weeks in females of the high dose group. Platelets were significantly increased only in females of the high dose group at 13 weeks (Table 9). 
TABLE 6. Body Weights $(g)$ of Male Rats Exposed to Lewisite (Mean \pm SE)

\begin{tabular}{|c|c|c|c|c|c|c|c|c|}
\hline \multirow{3}{*}{$\frac{\text { Week }}{0}$} & \multirow{2}{*}{\multicolumn{2}{|c|}{0}} & \multirow[b]{2}{*}{0.01} & \multicolumn{2}{|c|}{ Dose $(\mathrm{mg} / \mathrm{kg} /$ day $)$} & \multirow{2}{*}{\multicolumn{2}{|c|}{1.0}} & \multirow[b]{2}{*}{2.0} \\
\hline & & & & 0.1 & 0.5 & & & \\
\hline & 362 & $\pm \quad 4.9$ & $368 \neq 4.4$ & $372 \pm 5.5$ & $374 \pm 7.0$ & 370 & \pm 4.7 & $374 \pm 6.4$ \\
\hline 1 & 399 & \pm 6.1 & $408 \neq 5.1$ & $412 \pm 6.3$ & $418 \neq 10.0 \uparrow \uparrow$ & 400 & $\pm 8.3 \uparrow \uparrow$ & $408 \pm 11.2 \uparrow$ \\
\hline 2 & 426 & $\pm \quad 7.6$ & $435 \pm 6.2$ & $438 \neq 5.8$ & $444 \div 11.8 \uparrow \uparrow$ & 429 & $\neq 9.1 \uparrow t$ & $435 \pm 13.7 \uparrow$ \\
\hline 3 & 454 & * 9.2 & $460 \pm 6.7$ & $463 \pm 7.1$ & $468 * 12.5 \uparrow \uparrow$ & 452 & $\pm 9.3 \uparrow \uparrow$ & $458 \pm 15.2 \uparrow$ \\
\hline 4 & 472 & $\neq 12.0$ & $482 \pm 8.5$ & $486 \neq 9.1$ & $489 \pm 13.9 \uparrow \uparrow$ & 472 & $\pm 10.1 \uparrow \uparrow$ & $473 \pm 17.2 \uparrow$ \\
\hline 5 & 491 & \pm 13.0 & $497 \pm 9.7$ & $502 \neq 9.4$ & $509 \neq 14.5 \uparrow \uparrow$ & 494 & $\pm 11.2 \uparrow \uparrow$ & $487 \pm 17.1 \uparrow$ \\
\hline 6 & 500 & \pm 15.5 & $503 \pm 10.4$ & $515 \neq 10.0$ & $522=18.4 \uparrow \uparrow$ & 510 & $\pm 12.1 \uparrow \uparrow$ & $497 \pm 19.4 \uparrow$ \\
\hline 7 & 516 & $\neq 17.1$ & $526 \neq 10.8$ & $533 \pm 10.7$ & $537 * 21.2 \uparrow \uparrow$ & 530 & $\neq 11.9 \uparrow \uparrow$ & $516 \pm 21.3 \uparrow$ \\
\hline 8 & 530 & \pm 17.7 & $539 \neq 10.9$ & $548 \pm 12.1$ & $553 \pm 21.4 \uparrow \uparrow$ & 547 & $\pm 14.3 \uparrow t$ & $534 \pm 20.8 \uparrow$ \\
\hline 9 & 539 & \pm 18.6 & $550 \neq 12.3$ & $557 \pm 13.8$ & $566 \pm 23.5 \uparrow \uparrow$ & 537 & $\pm 23.2 \uparrow$ & $530 \pm 19.6 \uparrow$ \\
\hline 10 & 558 & \pm 20.7 & $566 \neq 12.7$ & $562 \pm 17.1$ & $575 \neq 23.4 \uparrow \uparrow$ & 559 & $\neq 25.7 \uparrow$ & $537 \pm 23.0 \uparrow$ \\
\hline 11 & 554 & \pm 15.8 & $571 \neq 13.5$ & $571 \pm 17.0$ & $576 \div 26.9 \uparrow \uparrow$ & 574 & $\neq 37.81$ & $553 \pm 21.2 \uparrow$ \\
\hline 12 & 578 & \pm 22.8 & $583 \neq 14.7$ & $582 * 16.9$ & $578 \neq 32.9 \uparrow \uparrow$ & 576 & $\pm 39.2 \uparrow$ & $569 \pm 23.7 \uparrow$ \\
\hline 13 & 594 & \pm 24.0 & $594 \pm 15.0$ & $594 * 17.0$ & $593 \pm 31.1 \uparrow \uparrow$ & 592 & $\pm 43.0 \uparrow$ & $582 \pm 24.1 \uparrow$ \\
\hline $\begin{array}{c}\uparrow \text { The } \\
\uparrow \uparrow \text { The } \\
n=\end{array}$ & 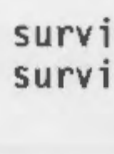 & $\begin{array}{l}\text { iving a } \\
\text { iving a }\end{array}$ & $\begin{array}{l}15 \text { is less } \\
15 \text { is more }\end{array}$ & $\begin{array}{l}5 . \\
\text { n } 5 .\end{array}$ & & & & \\
\hline
\end{tabular}


TABLE 7. Body Weights $(g)$ of Female Rats Exposed to Lewisite (Mean \pm SE)

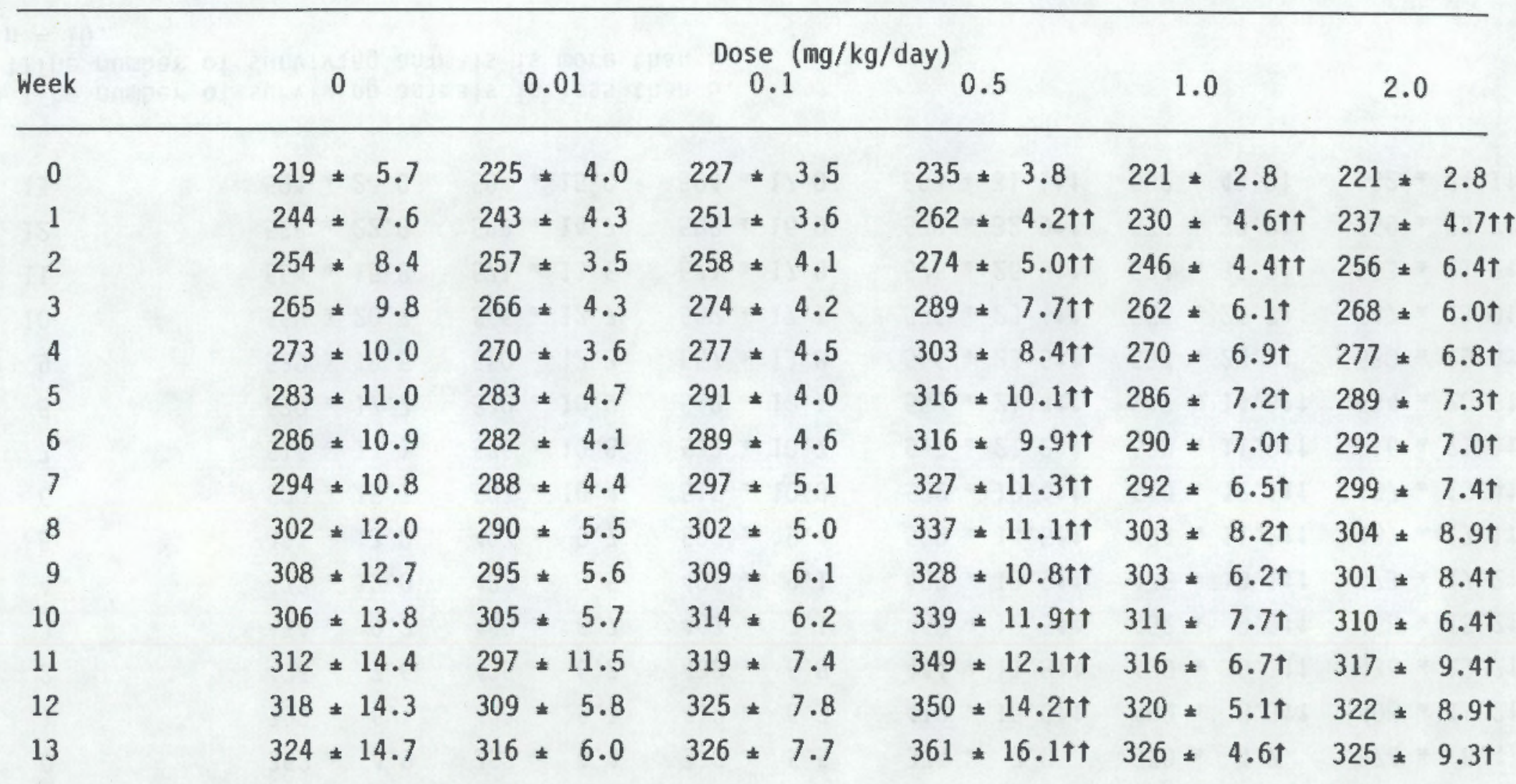

$\uparrow$ The number of surviving animals is less than 5 . $\uparrow \uparrow$ The number of surviving animals is more than 5 . $\mathrm{n}=10$. 

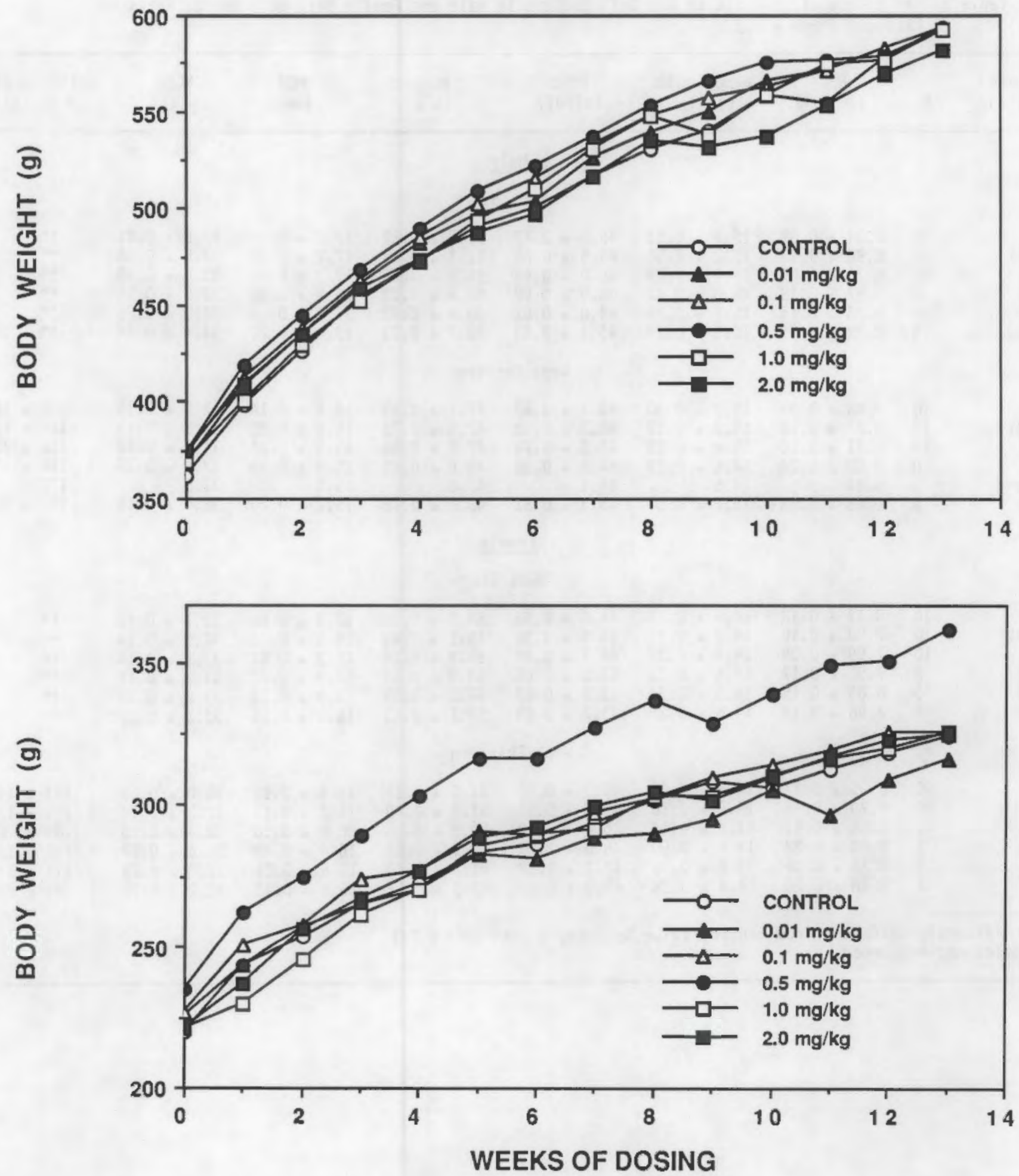

Figure 3. Body weight of male (upper panel) and female (lower panel) rats exposed to Lewisite for 13 weeks. 
Table 8. The Effect of Lewisite on Red Cell Indices in Male and Female Rats at 6 and 13 Weeks of Exposure (Mean $\neq$ SE)

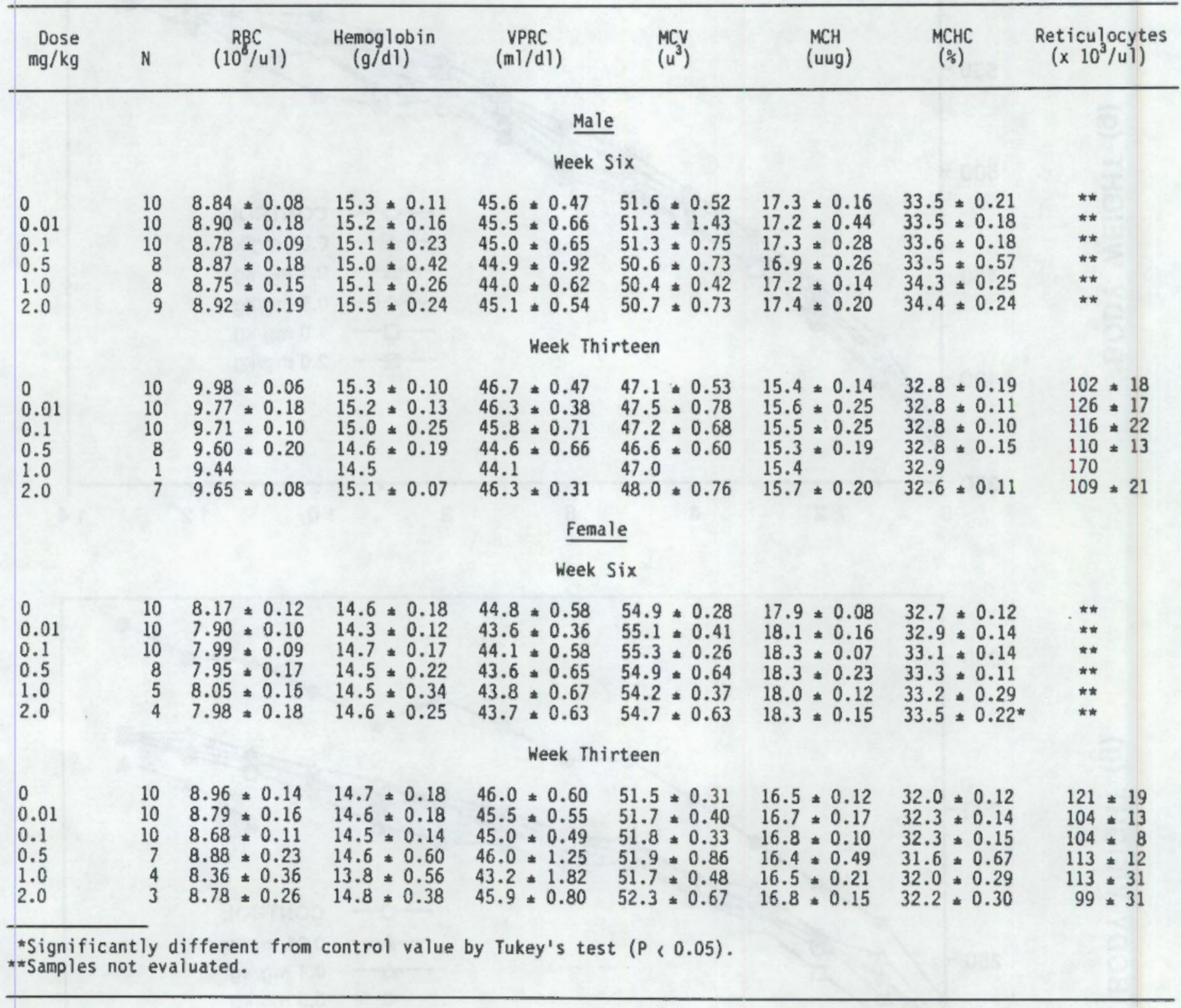


TABLE 9. The Effect of Lewisite on White Cell Indices in Male and Female Rats at 6 and 13 Heeks of Exposure (mean $\pm S E$ )

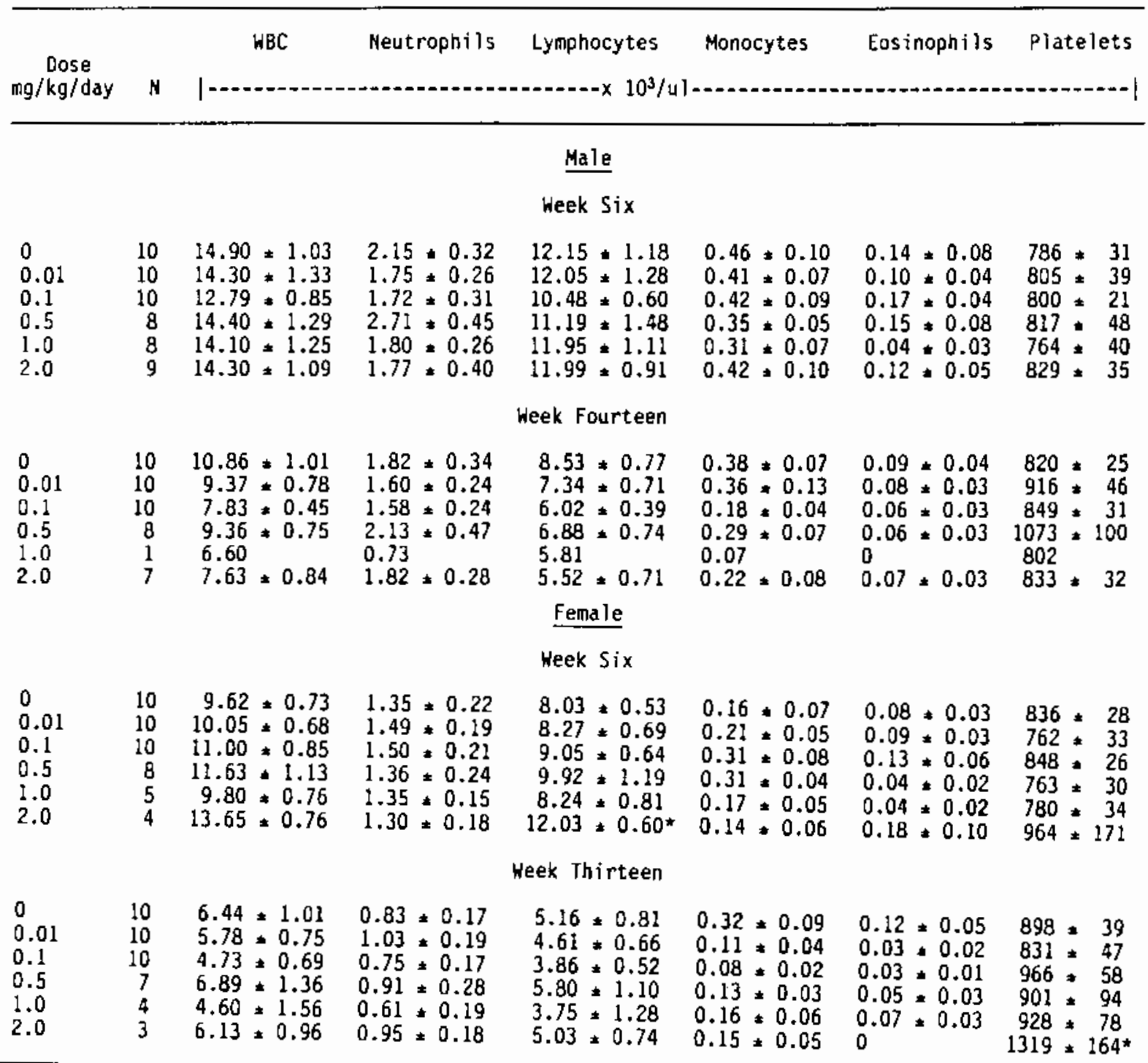

"Significantiy different from control value by Tukey's test $(\rho<0.05)$. 
Serum protein, creatinine, SGOT and SGPT were not altered in females dosed with Lewisite, but were decreased $(P<0.05)$ in treated males (Table 10). Serum protein and SGPT concentrations were significantly decreased only in males given $2.0 \mathrm{mg} / \mathrm{kg}$ Lewisite. Creatinine was decreased in males at the $0.5,1.0$ and $2.0 \mathrm{mg} / \mathrm{kg}$ dose groups. SGOT was decreased $(P<0.05)$ in male rats at all treatment groups, except the $1.0 \mathrm{mg} / \mathrm{kg}$ group which had only two surviving animals at terminal sacrifice. These changes in serum chemistry of the male rat did not appear to be dose-related. Mean serum protein, creatinine, SGOT, and SGPT values of the high-dose female group, although not significantly altered, tended to be decreased in magnitude similar to that of males and perhaps would be statistically significant if the number of surviving females were greater. BUN was not statistically altered at any treatment level for either sex. All mean values appear to be within normal historical range for Sprague-Dawley rats evaluated at this laboratory.

Statistically significant treatment-related differences were not found for body weights or organ weights at scheduled teminal sacrifice when expressed on an absolute or relative weight basis (Table 11).

Necropsy and Histopathology

A complete necropsy was performed on all control animals and those gavaged with Lewisite. A treatment-related lesion in the forestomach was the only gross lesion directly attributable to the intragastric administration of Lewisite. The lesion, consisting of firm masses on the mucosal surface, occurred in $80 \%(8 / 10)$ of the males and $40 \%(4 / 10)$ of females given $2.0 \mathrm{mg} / \mathrm{kg}$ Lewisite and in $10 \%(1 / 10)$ of the males in the $1.0 \mathrm{mg} / \mathrm{kg}$ dose group. A1l of the animals in the $2.0 \mathrm{mg} / \mathrm{kg}$ dose group that survived until scheduled terminal sacrifice and two which died after day 79 of the study had ulcerations of the forestomach. Gross lesions were sparse in the $1.0 \mathrm{mg} / \mathrm{kg}$ group; however, only $25 \%$ of the animals in this group survived until scheduled terminal sacrifice. No lesions were evident in the lower dose groups.

Histologic examination of the stomach sections of rats receiving 2.0 $\mathrm{mg} / \mathrm{kg}$ Lewisite revealed that the ulceration was characterized by necrosis of the stratified squamous epithelium accompanied by infiltration of numerous 
TABLE 10. The Effect of Lewisite on Serum Concentrations of Protein, BUN, Creatinine, SGOT and SGPT of Rats at 13 Weeks of Exposure

$($ mean $* \mathrm{SE})$

\begin{tabular}{|c|c|c|c|c|c|c|}
\hline $\begin{array}{c}\text { Dose } \\
\text { (mg/kg/day) } \\
\text { (IU) }\end{array}$ & $N$ & $\begin{array}{l}\text { Serum } \\
\text { Protein } \\
\text { (g/dl) }\end{array}$ & $\underset{(m g / d l)}{\text { BUN }}$ & $\begin{array}{c}\text { Creatinine } \\
(\mathrm{mg} / \mathrm{dl})\end{array}$ & $\begin{array}{l}\text { SGOT } \\
\text { (IU) }\end{array}$ & $\begin{array}{l}\text { SGPT } \\
\text { (IU) }\end{array}$ \\
\hline
\end{tabular}

\section{Females}

\begin{tabular}{|c|c|c|c|c|c|c|}
\hline 0 & 10 & $7.9 \div 0.18$ & $19 \pm 0.96$ & $1.4 \neq 0.065$ & $121 \div 20$ & $62 \pm 15.6$ \\
\hline 0.01 & 10 & $7.9 \div 0.16$ & $17 \pm 0.58$ & $1.4=0.065$ & $98 \div 9$ & $39 \pm 7.2$ \\
\hline 1 & 9 & $7.9 \neq 0.19$ & $19 \pm 0.90$ & $1.3 \neq 0.056$ & $107 \pm 10$ & $53 \pm 10.3$ \\
\hline .5 & 7 & $7.8 \div 0.09$ & $17 * 0.57$ & $1.2=0.044$ & $108 * 15$ & $47 \div 10.1$ \\
\hline 1.0 & 4 & $8.0 \star 0.25$ & $16 \div 0.71$ & $1.2 \pm 0.091$ & 162 & 27.8 \\
\hline .0 & 3 & $7.2 \neq 0.10$ & $17 * 1.20$ & $1.2 * 0.067$ & $96 \pm 9$ & 4.8 \\
\hline
\end{tabular}

Males

\begin{tabular}{|c|c|c|c|c|c|c|c|c|}
\hline 0 & 10 & $7.4 \pm 0.11$ & $16 \pm 0.73$ & $1.3 \neq 0.030$ & 94 & \pm 6 & $41 \pm$ & 4.2 \\
\hline 0.01 & 10 & $7.4 \pm 0.13$ & $17 \pm 0.52$ & $1.2 * 0.045$ & 83 & $\neq 3^{*}$ & 33 & 1.4 \\
\hline 0.1 & 10 & $7.1 \pm 0.08$ & $16 \pm 0.36$ & $1.1 \div 0.034$ & 82 & $\star 4^{\star}$ & 31 & 1.9 \\
\hline 0.5 & 8 & $7.1 \pm 0.14$ & $16 \pm 0.67$ & $1.0 \pm 0.044^{\star}$ & 83 & $\pm 4^{*}$ & 32 & 2.9 \\
\hline 1.0 & 2 & $7.1 \neq 0.10$ & $16 \pm 1.00$ & $1.0 \pm 0.200^{\star}$ & 114 & \pm 38 & 30 & 3.0 \\
\hline 2.0 & 7 & $6.7 \neq 0.05^{\star}$ & $15 \pm 0.62$ & $0.9 \neq 0.052^{*}$ & 83 & \pm 4 * & $21 \pm$ & $3.1^{*}$ \\
\hline
\end{tabular}

*Significantly different from control value by Tukey's test $(P<0.05)$. 
Table 11. Final Body Heights and Organ Weights of Rats Orally Exposed to Lewisite for 13 Heeks (Mean * SE).

\begin{tabular}{|c|c|c|c|c|c|c|c|c|c|c|c|c|c|c|c|c|}
\hline \multirow{2}{*}{$\begin{array}{c}\text { Dose } \\
\mathrm{mg} / \mathrm{kg} / \text { day }\end{array}$} & \multirow[b]{2}{*}{$N$} & \multirow{2}{*}{$\begin{array}{l}\text { Body } \\
\text { Height } \\
\text { (g) }\end{array}$} & \multicolumn{2}{|c|}{ Adrenal } & \multicolumn{2}{|c|}{ Brain } & \multicolumn{2}{|c|}{ Heart } & \multicolumn{2}{|c|}{ Kidney } & \multicolumn{2}{|c|}{ Liver } & \multicolumn{2}{|c|}{ Thymus } & \multicolumn{2}{|c|}{ Gonads } \\
\hline & & & $m g$ & $\mathrm{mg} / 100 \mathrm{~g}$ & $\overline{9}$ & $g / 100 \mathrm{~g}$ & 9 & 971009 & $\mathrm{~g}$ & $9 / 1009$ & 9 & $9 / 1009$ & 9 & $9 / 1009$ & $9 \quad 9$ & $7100 \mathrm{~g}$ \\
\hline \multicolumn{17}{|c|}{ Males } \\
\hline 0 & 10 & $\begin{array}{l}557.5 \\
\pm 22.7\end{array}$ & $\begin{array}{l}54 \\
\times 4\end{array}$ & $\begin{array}{l}10 \\
\pm 1\end{array}$ & $\begin{array}{l}2.17 \\
\pm 0.022\end{array}$ & $\begin{array}{l}0.395 \\
* 0.017\end{array}$ & $\begin{array}{l}1.52 \\
\pm 0.05\end{array}$ & $\begin{array}{l}0.274 \\
\pm 0.007\end{array}$ & $\begin{array}{l}1.91 \\
\pm 0.073\end{array}$ & $\begin{array}{l}0.345 \\
\star 0.013\end{array}$ & $\begin{array}{l}16.44 \\
\pm 1.28\end{array}$ & $\begin{array}{l}2.93 \\
\star 0.146\end{array}$ & $\begin{array}{l}288 \\
\pm 38\end{array}$ & $\begin{array}{l}51 \\
* 5\end{array}$ & $\begin{array}{l}1.83 \\
+0.04\end{array}$ & $\begin{array}{l}0.332 \\
\star 0.013\end{array}$ \\
\hline 0.01 & 10 & $\begin{array}{l}553.6 \\
\pm 20.5\end{array}$ & $\begin{array}{l}61 \\
\times 2\end{array}$ & $\begin{array}{l}11 \\
\pm 1\end{array}$ & $\begin{array}{l}2.16 \\
\star 0.028\end{array}$ & $\begin{array}{l}0.395 \\
\pm 0.013\end{array}$ & $\begin{array}{l}1.58 \\
\pm 0.05\end{array}$ & $\begin{array}{l}0.286 \\
\pm 0.009\end{array}$ & $\begin{array}{l}2.04 \\
\star 0.059\end{array}$ & $\begin{array}{l}0.371 \\
\pm 0.013\end{array}$ & $\begin{array}{l}16.94 \\
\pm 0.72\end{array}$ & $\begin{array}{l}3.07 \\
\pm 0.110\end{array}$ & $\begin{array}{l}310 \\
40\end{array}$ & $\begin{array}{l}55 \\
\star 6\end{array}$ & $\begin{array}{l}1.60 \\
\pm 0.12\end{array}$ & $\begin{array}{l}0.295 \\
\pm 0.027\end{array}$ \\
\hline 0.1 & 10 & $\begin{array}{l}558.5 \\
\pm 17.1\end{array}$ & $\begin{array}{l}59 \\
\times 2\end{array}$ & $\begin{array}{l}11 \\
\pm 0\end{array}$ & $\begin{array}{l}2.16 \\
\pm 0.026\end{array}$ & $\begin{array}{l}0.390 \\
\pm 0.012\end{array}$ & $\begin{array}{l}1.57 \\
\times 0.04\end{array}$ & $\begin{array}{l}0.282 \\
\pm 0.008\end{array}$ & $\begin{array}{l}1.94 \\
\pm 0.051\end{array}$ & $\begin{array}{l}0.349 \\
\pm 0.009\end{array}$ & $\begin{array}{l}16.06 \\
\star 0.57\end{array}$ & $\begin{array}{l}2.88 \\
\neq 0.069\end{array}$ & $\begin{array}{l}231 \\
\pm 15\end{array}$ & $\begin{array}{l}42 \\
* 2\end{array}$ & $\begin{array}{l}1.85 \\
\pm 0.05\end{array}$ & $\begin{array}{l}0.335 \\
\pm 0.014\end{array}$ \\
\hline 0.5 & 8 & $\begin{array}{l}560.5 \\
\pm 30.5\end{array}$ & $\begin{array}{l}61 \\
+3\end{array}$ & $\begin{array}{l}11 \\
1\end{array}$ & $\begin{array}{l}2.19 \\
\pm 0.031\end{array}$ & $\begin{array}{l}0.401 \\
\pm 0.027\end{array}$ & $\begin{array}{l}1.56 \\
\times 0.06\end{array}$ & $\begin{array}{l}0.283 \\
\pm 0.014\end{array}$ & $\begin{array}{l}1.98 \\
0.085\end{array}$ & $\begin{array}{l}0.359 \\
\pm 0.022\end{array}$ & $\begin{array}{l}16.93 \\
+1.10\end{array}$ & $\begin{array}{l}3.04 \\
\pm 0.166\end{array}$ & $\begin{array}{l}313 \\
\pm 22\end{array}$ & $\begin{array}{l}57 \\
\pm 5\end{array}$ & $\begin{array}{l}1.62 \\
\pm 0.14\end{array}$ & $\begin{array}{l}0.290 \\
+0.023\end{array}$ \\
\hline 1.0 & 1 & $\begin{array}{l}600.8 \\
\pm 0.0\end{array}$ & $\begin{array}{l}55 \\
\pm 0\end{array}$ & $\begin{array}{r}9 \\
+0\end{array}$ & $\begin{array}{l}2.08 \\
\pm 0\end{array}$ & $\begin{array}{l}0.346 \\
\pm 0\end{array}$ & $\begin{array}{l}1.78 \\
\pm 0\end{array}$ & $\begin{array}{l}0.295 \\
\pm 0\end{array}$ & $\begin{array}{l}1.95 \\
\star 0\end{array}$ & $\begin{array}{l}0.324 \\
.0\end{array}$ & $\begin{array}{l}17.33 \\
10\end{array}$ & $\begin{array}{l}2.88 \\
\star 0\end{array}$ & $\begin{array}{l}256 \\
\pm 0\end{array}$ & $\begin{array}{l}43 \\
\pm 0\end{array}$ & $\begin{array}{l}1.75 \\
.0\end{array}$ & $\begin{array}{l}0.292 \\
\star 0\end{array}$ \\
\hline 2.0 & 7 & $\begin{array}{l}543.5 \\
+21.7\end{array}$ & $\begin{array}{l}71 \\
\pm 5\end{array}$ & $\begin{array}{l}13 \\
\pm 1\end{array}$ & $\begin{array}{l}2.15 \\
* 0.04\end{array}$ & $\begin{array}{l}0.398 \\
\pm 0.016\end{array}$ & $\begin{array}{l}1.50 \\
\pm 0.06\end{array}$ & $\begin{array}{l}0.277 \\
\pm 0.011\end{array}$ & $\begin{array}{l}1.91 \\
\star 0.073\end{array}$ & $\begin{array}{l}0.352 \\
\pm 0.008\end{array}$ & $\begin{array}{l}15.72 \\
\pm 0.69\end{array}$ & $\begin{array}{l}2.90 \\
\pm 0.088\end{array}$ & $\begin{array}{l}240 \\
+20\end{array}$ & $\begin{array}{l}45 \\
+5\end{array}$ & $\begin{array}{l}1.78 \\
\pm 0.07\end{array}$ & $\begin{array}{l}0.330 \\
\pm 0.018\end{array}$ \\
\hline \multicolumn{17}{|c|}{ Females } \\
\hline & & & & & & & & & & & & & & & mg & $\begin{array}{l}\mathrm{mg} / \\
100 \mathrm{~g}\end{array}$ \\
\hline 0 & 10 & $\begin{array}{l}299.8 \\
\pm 13.5\end{array}$ & $\begin{array}{l}71 \\
-4\end{array}$ & $\begin{array}{l}24 \\
+1\end{array}$ & $\begin{array}{l}1.99 \\
\pm 0.033\end{array}$ & $\begin{array}{l}0.678 \\
\pm 0.032\end{array}$ & $\begin{array}{l}0.960 \\
\pm 0.034\end{array}$ & $\begin{array}{l}0.323 \\
\pm 0.010\end{array}$ & $\begin{array}{l}1.09 \\
* 0.032\end{array}$ & $\begin{array}{l}0.367 \\
* 0.012\end{array}$ & $\begin{array}{l}8.90 \\
\pm 0.50\end{array}$ & $\begin{array}{l}2.97 \\
* 0.117\end{array}$ & $\begin{array}{l}255 \\
\pm 31\end{array}$ & $\begin{array}{l}87 \\
\pm 10\end{array}$ & $\begin{array}{l}37 \\
* 3\end{array}$ & $\begin{array}{l}12 \\
* 1\end{array}$ \\
\hline 0.01 & 10 & $\begin{array}{l}295.9 \\
+5.2\end{array}$ & $\begin{array}{l}72 \\
\pm 6\end{array}$ & $\begin{array}{l}24 \\
\pm 2\end{array}$ & $\begin{array}{l}1.96 \\
* 0.029\end{array}$ & $\begin{array}{l}0.665 \\
\star 0.015\end{array}$ & $\begin{array}{l}0.957 \\
\pm 0.046\end{array}$ & $\begin{array}{l}0.324 \\
* 0.016\end{array}$ & $\begin{array}{l}1.12 \\
\neq 0.044\end{array}$ & $\begin{array}{l}0.379 \\
\pm 0.016\end{array}$ & $\begin{array}{l}\text { B.66 } \\
\bullet 0.37\end{array}$ & $\begin{array}{l}2.93 \\
\pm 0.117\end{array}$ & $\begin{array}{l}246 \\
+16\end{array}$ & $\begin{array}{l}83 \\
+6\end{array}$ & $\begin{array}{l}44 \\
\pm 3\end{array}$ & $\begin{array}{l}15 \\
\pm 1\end{array}$ \\
\hline 0.1 & 10 & $\begin{array}{l}303.7 \\
\pm 7.0\end{array}$ & $\begin{array}{l}72 \\
\pm 2\end{array}$ & $\begin{array}{l}24 \\
1\end{array}$ & $\begin{array}{l}1.99 \\
=0.030\end{array}$ & $\begin{array}{l}0.661 \\
\pm 0.023\end{array}$ & $\begin{array}{l}0.986 \\
+0.020\end{array}$ & $\begin{array}{l}0.326 \\
* 0.009\end{array}$ & $\begin{array}{l}1.10 \\
\pm 0.024\end{array}$ & $\begin{array}{l}0.365 \\
\pm 0.013\end{array}$ & $\begin{array}{l}9.08 \\
=0.22\end{array}$ & $\begin{array}{l}3.00 \\
\star 0.099\end{array}$ & $\begin{array}{l}215 \\
\times 23\end{array}$ & $\begin{array}{l}72 \\
\pm 9\end{array}$ & $\begin{array}{l}36 \\
\star 3\end{array}$ & $\begin{array}{l}12 \\
\star 1\end{array}$ \\
\hline 0.5 & 6 & $\begin{array}{l}339.2 \\
\pm 17.0\end{array}$ & $\begin{array}{l}65 \\
77\end{array}$ & $\begin{array}{l}20 \\
\pm 2\end{array}$ & $\begin{array}{l}1.94 \\
\pm 0.016\end{array}$ & $\begin{array}{l}0.580 \\
\pm 0.030\end{array}$ & $\begin{array}{l}1.067 \\
\pm 0.024\end{array}$ & $\begin{array}{l}0.318 \\
\pm 0.014\end{array}$ & $\begin{array}{l}1.15 \\
\star 0.053\end{array}$ & $\begin{array}{l}0.343 \\
-0.018\end{array}$ & $\begin{array}{l}10.00 \\
* 0.62\end{array}$ & $\begin{array}{l}2.94 \\
* 0.069\end{array}$ & $\begin{array}{l}253 \\
\pm 31\end{array}$ & $\begin{array}{l}74 \\
\pm 7\end{array}$ & $\begin{array}{l}38 \\
\pm 5\end{array}$ & $\begin{array}{l}11 \\
\pm 1\end{array}$ \\
\hline 1.0 & 4 & $\begin{array}{l}301.1 \\
\pm 4.0\end{array}$ & $\begin{array}{l}75 \\
\pm 7\end{array}$ & $\begin{array}{l}25 \\
-2\end{array}$ & $\begin{array}{l}1.91 \\
* 0.034\end{array}$ & $\begin{array}{l}0.635 \\
\pm 0.013\end{array}$ & $\begin{array}{l}1.035 \\
\pm 0.038\end{array}$ & $\begin{array}{l}0.344 \\
\pm 0.010\end{array}$ & $\begin{array}{l}1.15 \\
\pm 0.051\end{array}$ & $\begin{array}{l}0.383 \\
\pm 0.016\end{array}$ & $\begin{array}{l}9.95 \\
\pm 0.57\end{array}$ & $\begin{array}{l}3.31 \\
\pm 0.192\end{array}$ & $\begin{array}{l}248 \\
* 42\end{array}$ & $\begin{array}{l}83 \\
\pm 14\end{array}$ & $\begin{array}{l}35 \\
+7\end{array}$ & $\begin{array}{l}12 \\
* 3\end{array}$ \\
\hline 2.0 & 3 & $\begin{array}{l}299.1 \\
\pm 9.4\end{array}$ & $\begin{array}{l}84 \\
\pm 4\end{array}$ & $\begin{array}{l}28 \\
\pm 1\end{array}$ & $\begin{array}{l}1.94 \\
=0.028\end{array}$ & $\begin{array}{l}0.651 \\
\star 0.013\end{array}$ & $\begin{array}{l}1.018 \\
\pm 0.044\end{array}$ & $\begin{array}{l}0.340 \\
\pm 0.013\end{array}$ & $\begin{array}{l}1.13 \\
0.045\end{array}$ & $\begin{array}{l}0.378 \\
\pm 0.018\end{array}$ & $\begin{array}{l}10.22 \\
\pm 0.50\end{array}$ & $\begin{array}{l}3.42 \\
\pm 0.195\end{array}$ & $\begin{array}{l}199 \\
\pm 23\end{array}$ & $\begin{array}{l}67 \\
\pm 8\end{array}$ & $\begin{array}{l}46 \\
\pm 5\end{array}$ & $\begin{array}{l}16 \\
\pm 2\end{array}$ \\
\hline
\end{tabular}


neutrophils and macrophages, proliferation of neocapillaries which were often distended and congested, hemorrhage, edema and fibroblast proliferation. In a few cases the squamous epithelium immediately adjacent to ulcerated areas was hyperplastic. In severe cases the necrosis and accompanying inflammation extended throughout the thickness of the mucosa, submucosa and muscular layers of the stomach and involved the serosa. Epithelial hyperplasia and hyperkeratosis of the forestomach without ulceration was observed in the only surviving male rat in the $1.0 \mathrm{mg} / \mathrm{kg}$ group.

Acute inflamation of the glandular stomach was detected in $10 \%(1 / 10)$ of the males and $30 \%(3 / 10)$ of the females in the $2.0 \mathrm{mg} / \mathrm{kg}$ group. The lesion, present in only early death animals, was very mild and consisted of necrosis of the most superficial epithelial cells of the glandular mucosa plus cellular debris mixed with mucus, neutrophils and macrophages adhering to the mucosal surface. Because of its mild nature and superficial location, the presence of this lesion may have been obscured by autolytic changes in other early death animals that may not have been necropsied immediately after death.

All early deaths were in the Lewisite treatment groups (Figure 2.) and were examined microscopically. All animals examined had acute severe inflammatory lesions affecting some part of the respiratory tract. In all cases except one male in the $0.5 \mathrm{mg} / \mathrm{kg}$ group, the respiratory lesions were considered severe enough to be the cause of death. Tissues affected by the lesions included the larynx, trachea, lungs and nasal tissues although not all respiratory tissues were involved in every animal. Lesions in the larynx and trachea were characterized by edema, acute epithelial necrosis and infiltration of submucosal tissues with neutrophils. Usually the lumen of affected larynx or trachea was completely or partially filled with exudate consisting of a mixture of proteinaceous fluid, fibrin, cellular debris, mucus and neutrophils. In some cases, large intrapulmonary airways had similar lesions. Less frequently, similar changes affected terminal airways and adjacent pulmonary parenchyma. Similar lesions consisting of acute necrosis, edema and inflammation affected nasal respiratory and olfactory epithelium. There nasal lesions were most frequent and most severe in the most posterior nasal section at the level of the second molar teeth, but 
occasionally nasal involvement extended anteriorly to the level of the incisor teeth.

Nearly $90^{\circ}$ of the animals in this study, including control animals, had reactive hyperplasia of the mandibular lymph nodes. The lesion consisted of hypercellularity and loss of nodal organization due to proliferation of numerous immature "reactive" lymphocytes. The high incidence of this lesion may be due to irritation of tissues in the pharynx by the daily gavage procedure, although chronic inflanmation of the pharynx was not as common as the hyperplastic changes in mandibular lymph nodes. Therefore, the cause of this change was undetermined.

Subacute myocarditis was observed in a number of control and treated animals, but the incidence of this minimal lesion was not treatment-related nor was the cause determined. When observed, the lesion was characterized by necrosis of myocardial fibers and infiltration of neutrophils and macrophages which phagocytize the necrotic cellular debris. Necrotic fibers were eosinophilic and the nuclei were pyknotic or fragmented. Typically the lesion occurred as one or more tiny foci involving only a few mocardial fibers.

Lymphoid necrosis of the spleen, lymph nodes and thymus observed in some animals was not treatment related but could possibly be attributed to non-specific change induced by stress. The few other microscopic lesions observed in this study were considered incidental findings unrelated to administration of Lewisite and of no consequence in interpretation of results. 


\section{DISCUSSION}

The formation of lesions in the forestomach of the rat at the site of the Lewisite application was the primary toxic effect of Lewisite exposure. Lesions were present in all the $2.0 \mathrm{mg} / \mathrm{kg}$ Lewisite animals that survived until scheduled terminal sacrifice. We found no significant decrease in body weights of the $2.0 \mathrm{mg} / \mathrm{kg}$ survivors which had the high incidence of forestomach lesions. Body weights were significantly reduced in rats having a high incidence of forestomach lesions after receiving $0.3 \mathrm{mg} / \mathrm{kg} 5 \mathrm{ulfur}$ mustard in a study of a similar design (Sasser et al. 1989).

The forestomach appeared to be more sensitive to Lewisite than did the glandular stomach as only mild inflammation of the glandular tissue was detected in some of the early death animals. The reason for this apparent sensitivity is not known, but could possibly be the result of direct deposition of the test material onto the affected tissue or may indeed indicate a sensitive tissue compared to the glandular stomach. The forestomach has been shown to be more sensitive than the glandular stomach to acute and repeated gavaging of ethyl acrylate (Ghanayem, et al. 1985a, 1985b, 1986) as well as the sulfur mustard studies (Sasser et al. 1989). Evidence of dose-related pathology was not found in the intestine.

We found no evidence that the forestomach lesions observed in this study were precancerous nor did our earlier studies show that Lewisite was mutagenic in the Ames Assay or in Chinese hamster ovary cells (Stewart, et al.. 1989; Jostes, et al., 1989). Lesions of the forestomach have been reported for many chemical irritants after oral or gavage exposure. A relationship between forestomach lesions and squamous ce1l carcinomas has recently been reported for butylated hydroxyanisole given in the feed (Ito et al., 1982, 1983) and for arisolochic acid given by gavage (Mengs, 1983). Induction of squamous cell carcinomas of the forestomach of the rat was reported after oral gavage with methyl bromide (Danse et al., 1984: Boorman et al., 1986). In recent reviews on this subject, as many as 60 compounds were found which demonstrated carcinogenic activity of the forestomach (Kroes and Webster, 1986: Webster and Kroes, 1988). Ito et a1. (1982) postulated that increased proliferation of cells provides a favorable environment for the development of cancer but the fact that so many chemicals are able to initiate this 
process suggests that the cause may be an unspecific response (Webster and Kroes, 1988). Induction of forestomach carcinoma is no doubt both time- and dose-dependent and our study was not of sufficient length to determine the malignant nature of the lesions.

With the exception of one animal, all early deaths in this study could be attributed to lesions of the respiratory tract. Indeed, a few animals that survived until scheduled sacrifice also had inflammatory lesions involving the respiratory tract. The probable cause of these respiratory lesions was the accidental deposition or induced reflux of the test material into the pharynx and subsequent aspiration of the lewisite into the larynx, trachea, lungs and nasal cavity. Evidence of respiratory lesions was not found when sulfur mustard, another strong vesicant, was administered at concentrations sufficiently great to cause weight loss and to induce forestomach lesions similar to those reported in this study (Sasser et al.. 1989). Lewisite exposure, unlike the action of sulfur mustard in which pain may be delayed, is characterized by immediate onset of pain; gastrointestinal and respiratory tissues are especially known to be sensitive (Gates et al., 1946). Indeed, Lewisite may have been irritating enough to evoke an imnediate attempt by the rat to reject the material causing more accidental dosing trauma or actual aspiration of Lewisite into the respiratory tract than in the case of sulfur mustard.

The absence of statistically significant changes in serum protein, creatinine, SGOT and SGPT in female rats probably does not indicate a strong sex-related difference in response to Lewisite. A comparison of controls and high-dose group indicates that the percentage decrease was approximately the same for males and females, even though the difference was statistically significant only for males. The number of surviving females in the high-dose group was probably insufficient to detect this difference statistically. The biological implications of these changes in the male are difficult to interpret in view of the absence of changes in body weights and organ weights. The effect may be related to altered metabolic activity resulting from the burden of the forestomach lesions.

In summary, daily intragastric administration of Lewisite to rats at dosage rates of $0.01,0.1,0.5,1.0$ and $2.0 \mathrm{mg} / \mathrm{kg}$ for 13 weeks did not affect hematological indices, growth, or terminal organ weights. Decreases 
in serum protein, creatinine, SGOT and SGPT were found in male but not in female rats. Ulceration of the forestomach was the major effect attributable to Lewisite exposure. Hyperplasia of the stratified squamous epithelium of the forestomach and mild inflamation of the superficial muscosa in the glandular stomach were also observed. The respiratory tract was easily irritated by Lewisite during the gavaging procedure. The no-effect dose level for Lewisite in this 90-day subchronic study appears to be greater than $0.5 \mathrm{mg} / \mathrm{kg}$ and less than $1.0 \mathrm{mg} / \mathrm{kg}$ but this effect can not be determined accurately because of the low number of survivors in the $1.0 \mathrm{mg} / \mathrm{kg}$ dose group. 


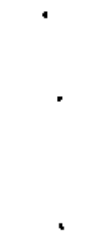




\section{LITERATURE CITED}

Auerbach, C. and J.M. Robson. 1947. Tests of chemical substances for mutagenic action. Proc. Royal Soc. Edinburgh 62B: 284-291.

Boorman, G.A., H.L. Hong, C.W. Jameson, K. Yoshitomi and R.R. Maronpot. 1986. Regression of methyl bromide-induced forestomach lesions in the rat. Toxicol. and Appl. Pharmac. 86: 131-139.

Cameron, G.R., H.M. Carleton and R.H.D. Short. 1946. Pathological changes induced by Lewisite and Allied Compounds. J. Pathol. Bacteriol. 58, 411-422.

Cassarett, L.J. and J. Doull. 1986. Toxicology. The Basic Science of Poisons, 3rd Ed., MacMillan Publishers, New York, NY.

Danse, L.H.J.C., F.L. Van Velsen and C.A. Van der Heijden. 1984. Methylbromide: Carcinogenic effects in the rat forestomach. Toxicol. Appl. Pharmacol. 22: 262-271.

Gates, M., J.W. Witliams and J. A. Zapp. 1946. Arsenicals. Chemical Warfare Agents and Related Chemical Problems, Summary Technical Report of Division 9, National Defense Research Committee, Vol. 1, Parts I and II, pp. 83-114. Washington, D.C.

Ghanayem, B.I., R.R. Maronpot and H.B. Matthews. 1985a. Ethyl acrylateinduced gastric toxicity. I. Effect of single and repetitive dosing. Toxicol. Appl. Pharmacol. 80: 323-335.

Ghanayem, B.I., R.R. Maronpot and H.B. Matthews. 1985b. Ethyl acrylateinduced gastric toxicity. II. Structure-toxicity relationship and mechanism. Toxicol. App 1. Pharmacol, 80: 336-344.

Ghanayem, B.I., R.R. Maronpot and H.B. Matthews. 1986. Ethyl acrylateinduced gastric toxicity. III. Development and recovery of lesions. Toxicol. Appl. Pharmacol. 83: 576-583.

Hackett, P.L., L.B. Sasser, R.L. Rommereim, J.A. Cushing, R.L. Buschbom and D.R. Kalkwarf. 1987. Teratology studies on Lewisite and sulfur mustard agents: Effects of Lewisite in rats and rabbits. AD-A187432. U.S. Army Medical Research and Development Command, Fort Detrick, Frederick, MD.

Inns, R.H., J.E. Bright and T.C. Marrs. 1988. Comparative acute systemic toxicity of sodium arsenite and dichloro(2-chlorovinyl)arsine in rabbits. Toxicology 51: 213-222.

Ito, N., A. Haviwara, M. Shibata, T. Ogiso and S. Fukushima. 1982. Induction of squamous cell carcinoma in the forestomach of F344 rats treated with butylated hydroxyanisole. GANN 73: 332-334. 
Ito, N., S. Fukushima, A. Hagiwara, M. Shibata and T. Ogiso. 1983. Carcinogenicity of butylated hydroxyanisole in F344 rats. J. Nat1. Cancer Inst. $70: 343-349$.

Jostes, R.F. Jr., R.J. Rausch and L.B. Sasser. 1989. Toxicology studies of Lewisite and sulfur mustard: Genetic toxicity of sulfur mustard (HD) in Chinese hamster ovary cells. U.S. Army Medical Research and Development Command, Ft. Detrick, Frederick, MD.

Kroes, R. and P.W. Webster. 1986. Forestomach carcinogens: Possible mechanisms of action. Food Chem. Tox. 24: 1083-1089.

Krause, H. and E.I. Grussendorf. 1978. Syntony of Bowen's disease and Lewisite scar. Hautarzt 29: 490-493.

Leonard, A. and R.R. Lauwerys. 1980. Carcinogenicity, teratogenicity and mutagenicity of arsenic. Mutation Res. 75: 49-62.

Loveless, A. 1951. Qualitative aspects of the chemistry and biology of radiomimetic (mutagenic) substances. Nature 167: 338-342.

Mengs, U. 1983. On the histopathogenesis of rat forestomach carcinoma caused by aristolochic acid. Arch. Toxicol. 52: 209-220.

Mohler, H. and J. Sorge. 1939. Chemical warfare materials. XII. Light absorption by nose and throat, lung and skin poisons in ultraviolet of short wave length. Helv. Chim. Acta 22: 235-239.

National Academy of Science. 1977. Medical and Biologic Effects of Environmental Pollutants, Arsenic. Washington, D.C.

Rewick, R.T., M.L. Schumacher and D. L. Haynes. 1986. The uv absorption spectra of chemical agents and stimulants. Appl. Spectroscopy 40: 152-156.

Rosenblatt, D.H., T.A. Miller, J.C. Dacre, I. Muul and D.R. Cogley (eds.). 1975. Problem definition of potential environmental pollutants. II. Physical, chemical, toxicological and biological properties of 16 substances. In: U.S. Army Medical Bioengineering Research and Development Technical Report 7509. Fort Detrick, Frederick, MD.

SAS Institute, Inc. 1985. SAS User's Guide: Statistics Version, 5th Edition. Cary, NC: SAS Institute InC., 1985.

Sasser, L.B., J.A. Cushing, D.R. Kalkwarf and R.L. Miller, 1989. Toxicology studies on Lewisite and sulfur mustard: Subchronic toxicity of sulfur mustard in rats. U.S. Army Medical Research and Development Command, Fort Detrick, MD.

Stewart, D.L., E.J. Sass, L.K. Fritz and L.B. Sasser. 1989. Toxicology studies on Lewisite and sulfur mustard agents: Mutagenicity study of sulfur mustard in the Salmonella histidine reversion test. U.S. Army Medical Research and Development Command, Ft. Detrick, Frederick, MD. 
Sweet, D.V. 1987. Registry of Toxic Effects of Chemical Substances, Vol. 5. p. 1968. U.S. Government Printing Office, Washington, D.C.

Tukey, J.W. 1953. The problem of multiple comparisons. Ditto, Princeton University, $3996 \mathrm{pp}$.

Wada, S., Y. Nishimoto, M. Miyanishi, S. Kambe and R.W. Miller. 1968. Mustard gas as a cause of respiratory neoplasia in man. The Lancet 7753: 1161-1163.

Webster, P.W. and R. Kroes. 1988. Forestomach carcinogens: Pathology and Relevance to Man. Toxic. Pathol. 16: 165-171.

Yamakido, M. and T. Shigenobu. 1985. The causes of death in the retired workers of Okuno-Jima poison gas factory. Jpn. J. Med. 34: 311-322.

Zerbe, G.0. 1979. Randomization analysis of completely randomized design extended to growth and response curves. J. Am. Statistical Assoc. 79: 215221 . 
' 
PERSONNEL LIST

Function

Principal Investigator

Facility Manager

Solution Preparation and Analysis

Animal Exposures

Opthamology Evaluation

Henatology Evaluation

Pathologist

Necropsy Evaluation

Health Evaluation

Animal Care Center

Statistical Analyses

$\frac{y^{\prime} / 2+t_{2}}{\text { L.B. Sasser }}$
Name

L.B. Sasser

M.T. Karagianes

D.R. Kalkwarf

C.W. Lindenmeier

L.B. Sasser

C. Veverka, Jr.

J.A. Cushing

C.W. Lindenmeier

D.W. Shea

R.E. Weller

C.0. Romsos

P.W. Mellick

T.A. Breier

B.L. Champion

J.A. Cushing

C.W. Lindenmeier

M.O. Orgill

D.W. Shea

R.C. Zangar

S.E. Rowe

E.L. Weirman

R.F. Buschbom

$\frac{5 / 3 / 69}{\text { Date }}$ 


\section{STUDY DATES FOR LEWISITE 90-DAY SUBCHRONIC STUDY}

Animals arrival

Health evaluation

Exposure period

Hematology evaluation

Opthamology evaluation

Necropsy
$10 / 07 / 86$

$11 / 05 / 86$

$11 / 10 / 86$ to $02 / 12 / 87$

$12 / 17 / 86$ to $12 / 18 / 86$

$02 / 11 / 87$ to $02 / 13 / 87$

$10 / 03 / 86$

$01 / 30 / 87$

$02 / 11 / 87$ to $02 / 13 / 87$

Data are property of the U.S. Army and will be archived under the Army's direction at approved facilities. 
90-Day Subchronic Gavage Lewisite (L) in Rats

\section{Quality Assurance Statement}

Listed below are the phases and/or procedures included in the study described in this report which were reviewed by the Quality Assurance Unit specifically for this study and the dates the reviews were performed and findings reported to management. (All findings were reported to the study director or his designee at the time of the review.)

Phase/Procedure Reviewed

Serology

Dosing

Data

Dose Preparation

Necropsy

Blood Collection

Data

Data

Data

Final Report
Review Date

$10 / 31 / 86$

$11 / 14 / 86$

$1 / 15 / 87$

$1 / 30 / 87$

2/11-12/87

2/11-12/87

$5 / 14,18 / 87$

$8 / 12 / 87 \& 11 / 13 / 87$

$8 / 12 / 87$ \& $11 / 13 / 87$

7/6-7/89 \& 9/12,14,15/89
Date Findings Submitted in Writing to

Study Director/Management

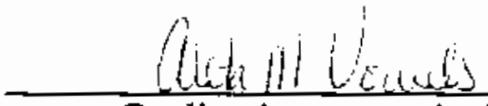

Quality Assurance Auditor

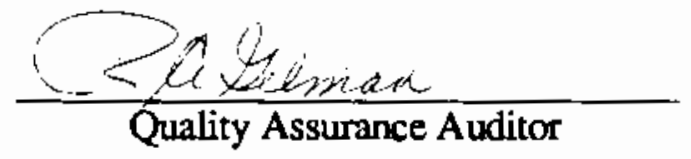

$11 / 03 / 86$

$11 / 17 / 86$

$1 / 19 / 87$

$2 / 11 / 87$

$2 / 12 / 87$

$2 / 12 / 87$

$5 / 21 / 87$

$11 / 13 / 87$

$11 / 13 / 87$

$10 / 8 / 89$

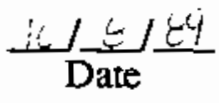

$\frac{1 .+2}{\text { Date }}$ 


\section{$\underline{\text { OFFSITE }}$}

Commander (25)

U.S. Army Biomedical Research and Development Laboratory

Attn: SGRD-UBZ-RA

Fort Detrick

Frederick, MD 21701-5010

Commander (2)

U.S. Army Medical Research and Development Command

Attn: SGRD-PLE

Fort Detrick

Frederick, MD 21701-5012

Commander (2)

U.S. Army Medical Research Institute of Chemical Defense Attn: SGRD-UV-ZB

Aberdeen Proving Grounds, MD 21010-5425

\section{ONSITE}

DOE Operations Office

E.C. Norman

D.L. Sours

Pacific Northwest Laboratory

Publishing Coordination

Technical Report Files (5)

L.B. Sasser (5)
U.S. Army Medical Research and Development Command (2) Attn: SGRD-RMI-S

Fort Detrick

Frederick, MD 217D1-5012

Chemical Effects Information Center (1)

0ak Ridge National Laboratory P.0. Box X

Oak Ridge, TN 37831

Defense Technical Information Center (DTIC)

Attn: DTIC-DDA

Cameron Station

Alexandria, VA 22314 